\title{
Towards Reversible High-Voltage Multi-Electron Reactions in Alkali-Ion Batteries Using Vanadium Phosphate Positive Electrode Materials
}

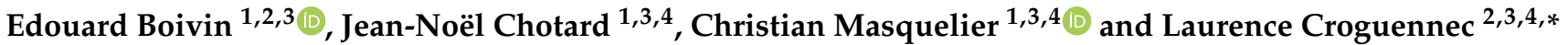 \\ 1 Laboratoire de Réactivité et de Chimie des Solides, CNRS-UMR 7314, Université de Picardie Jules Verne, \\ CEDEX 1, F-80039 Amiens, France; edouard.boivin@univ-lille.fr (E.B.); \\ jean-noel.chotard@u-picardie.fr (J.-N.C.); christian.masquelier@u-picardie.fr (C.M.) \\ 2 CNRS, Université Bordeaux, Bordeaux INP, ICMCB UMR 5026, F-33600 Pessac, France \\ 3 RS2E, Réseau Français sur le Stockage Electrochimique de l'Energie, FR CNRS 3459, CEDEX 1, \\ F-80039 Amiens, France \\ 4 ALISTORE-ERI European Research Institute, FR CNRS 3104, CEDEX 1, F-80039 Amiens, France \\ * Correspondence: laurence.croguennec@icmcb.cnrs.fr; Tel.: +33-(0)5-4000-2647
}

\section{check for} updates

Citation: Boivin, E.; Chotard, J.-N.; Masquelier, C.; Croguennec, L. Towards Reversible High-Voltage Multi-Electron Reactions in Alkali-Ion Batteries Using Vanadium Phosphate Positive Electrode Materials. Molecules 2021, 26, 1428. https://doi.org/10.3390/molecules 26051428

Academic Editor:

Myung-Hwan Whangbo

Received: 30 January 2021

Accepted: 1 March 2021

Published: 6 March 2021

Publisher's Note: MDPI stays neutral with regard to jurisdictional claims in published maps and institutional affiliations.

Copyright: (c) 2021 by the authors. Licensee MDPI, Basel, Switzerland. This article is an open access article distributed under the terms and conditions of the Creative Commons Attribution (CC BY) license (https:/ / creativecommons.org/licenses/by/ $4.0 /)$.

\begin{abstract}
Vanadium phosphate positive electrode materials attract great interest in the field of Alkaliion (Li, $\mathrm{Na}$ and K-ion) batteries due to their ability to store several electrons per transition metal. These multi-electron reactions (from $\mathrm{V}^{2+}$ to $\mathrm{V}^{5+}$ ) combined with the high voltage of corresponding redox couples (e.g., $4.0 \mathrm{~V}$ vs. for $\mathrm{V}^{3+} / \mathrm{V}^{4+}$ in $\left.\mathrm{Na}_{3} \mathrm{~V}_{2}\left(\mathrm{PO}_{4}\right)_{2} \mathrm{~F}_{3}\right)$ could allow the achievement the $1 \mathrm{kWh} / \mathrm{kg}$ milestone at the positive electrode level in Alkali-ion batteries. However, a massive divergence in the voltage reported for the $\mathrm{V}^{3+} / \mathrm{V}^{4+}$ and $\mathrm{V}^{4+} / \mathrm{V}^{5+}$ redox couples as a function of crystal structure is noticed. Moreover, vanadium phosphates that operate at high $\mathrm{V}^{3+} / \mathrm{V}^{4+}$ voltages are usually unable to reversibly exchange several electrons in a narrow enough voltage range. Here, through the review of redox mechanisms and structural evolutions upon electrochemical operation of selected widely studied materials, we identify the crystallographic origin of this trend: the distribution of $\mathrm{PO}_{4}$ groups around vanadium octahedra, that allows or prevents the formation of the vanadyl distortion $\left(\mathrm{O}^{\cdots} \mathrm{V}^{4+}=\mathrm{O}\right.$ or $\left.\mathrm{O} \cdots \mathrm{V}^{5+}=\mathrm{O}\right)$. While the vanadyl entity massively lowers the voltage of the $\mathrm{V}^{3+} / \mathrm{V}^{4+}$ and $\mathrm{V}^{4+} / \mathrm{V}^{5+}$ couples, it considerably improves the reversibility of these redox reactions. Therefore, anionic substitutions, mainly $\mathrm{O}^{2-}$ by $\mathrm{F}^{-}$, have been identified as a strategy allowing for combining the beneficial effect of the vanadyl distortion on the reversibility with the high voltage of vanadium redox couples in fluorine rich environments.
\end{abstract}

Keywords: batteries; positive electrode; vanadium phosphates; covalent vanadyl bond; mixed anion

\section{Introduction}

In the 2000s, the research on polyanion compounds as positive electrode materials was mainly motivated by the interesting properties of the low cost triphylite $\mathrm{LiFePO}_{4}$ [1-5] (olivine-type structure) providing long-term structural stability, essential for extensive electrochemical cycling and safety issues. In this material, the high voltage for the $\mathrm{Fe}^{2+} / \mathrm{Fe}^{3+}$ redox couple delivered in $\mathrm{LiFePO}_{4}$ (i.e., $3.45 \mathrm{~V}$ vs. $\mathrm{Li}^{+} / \mathrm{Li}$ vs. ca. $2.2 \mathrm{~V}$ in oxides) is due to the inductive effect of the phosphate group. Further exploitation of the inductive effect with fluorine and/or sulfate has led to materials such as $\mathrm{LiFeSO}_{4} \mathrm{~F}$ (Tavorite or Triplite structure) delivering an even higher voltage than $\mathrm{LiFePO}_{4}$ (i.e., $3.6 \mathrm{~V}$ and $3.9 \mathrm{~V} \mathrm{vs}$. $\mathrm{Li}^{+} / \mathrm{Li}$ for Tavorite and Triplite structures, respectively) [6,7]. However, these materials suffer from a deficit of capacity compared to the current best commercially available Li-ion positive electrode materials. $\mathrm{Li}_{2} \mathrm{FeSiO}_{4}$ has been proposed to overcome this issue by triggering both $\mathrm{Fe}^{2+} / \mathrm{Fe}^{3+}$ and $\mathrm{Fe}^{3+} / \mathrm{Fe}^{4+}$ redox couples but the strong structural changes involved seem to be detrimental to long-term performances [8]. To the best of our knowledge, this material is the only one providing a multi-electron reaction (i.e., exchange of more than one 
electron per transition metal) in iron-based polyanion systems while vanadium phosphate materials offer numerous such examples. Indeed, the ability of vanadium to be stabilized in the large range of oxidation states, from $\mathrm{V}^{2+}$ to $\mathrm{V}^{5+}$ (e.g., from $\mathrm{V}^{3+}$ in $\mathrm{Li}_{2} \mathrm{VPO}_{4} \mathrm{O}$ to $\mathrm{V}^{5+}$ in $\mathrm{VPO}_{4} \mathrm{O}$ ) [9-13] combined with the rather high voltage of the corresponding redox couples (e.g., $4.25 \mathrm{~V}$ vs. $\mathrm{Li}^{+} / \mathrm{Li}$ for $\mathrm{V}^{3+} / \mathrm{V}^{4+}$ in $\mathrm{LiVPO}_{4} \mathrm{~F}$ ) [14] could allow the achievement of high energy density thanks to reversible high-voltage multi-electron redox in Alkali-ion batteries (Figure 1).

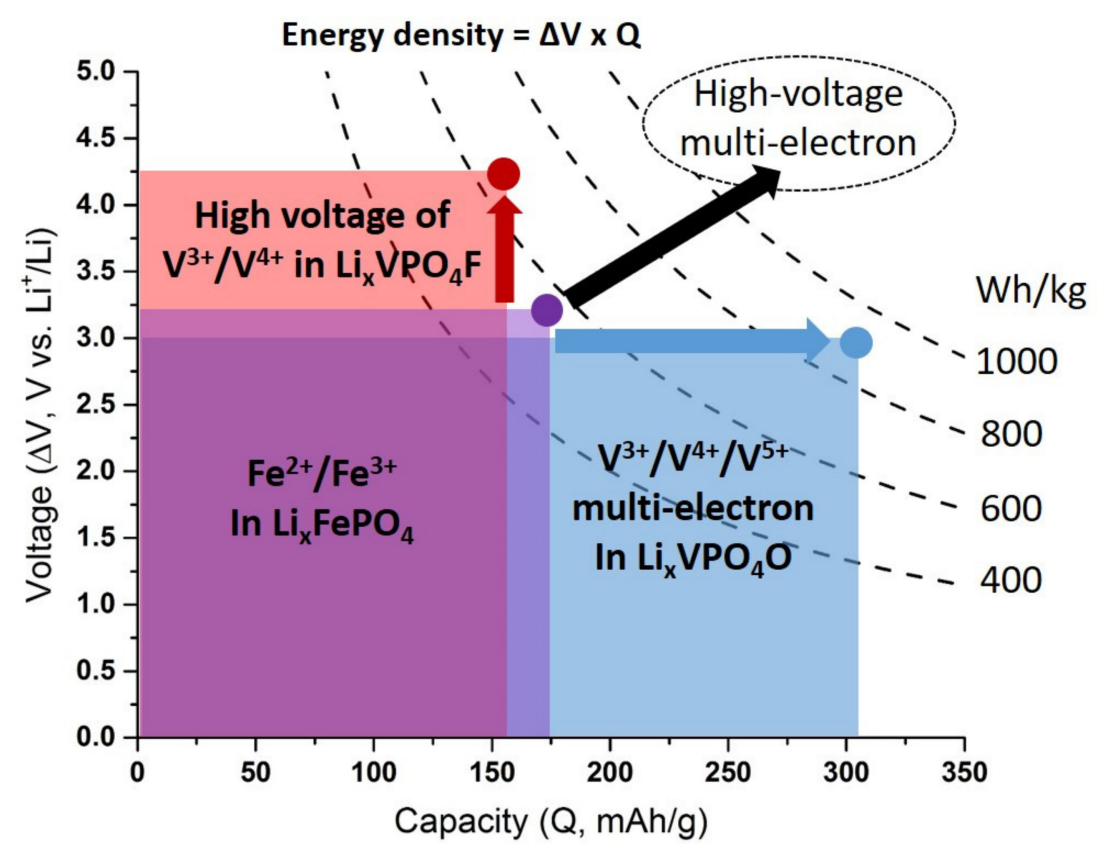

Figure 1. Voltage vs. capacity plot for $\mathrm{LiFePO}_{4}$ (purple), $\mathrm{LiVPO}_{4} \mathrm{~F}$ (red), $\mathrm{LiVPO}_{4} \mathrm{O}$ (blue). Combining the high voltage of $\mathrm{LiVPO}_{4} \mathrm{~F}$ with the high capacity of the multi-electron redox in $\mathrm{LiVPO}_{4} \mathrm{O}$ could allow the achievement of higher energy density through high voltage multi-electron redox. The dash lines represent constant energy densities in $\mathrm{Wh} / \mathrm{kg}$ of active positive electrode material.

However, depending on the geometry of the $\mathrm{VO}_{n}$ polyhedra, the positions of the $\mathrm{V}^{3+} / \mathrm{V}^{4+}$ and $\mathrm{V}^{4+} / \mathrm{V}^{5+}$ redox couples massively change. For instance, Tavorite $\mathrm{LiVPO}_{4} \mathrm{~F}$ operates at $4.25 \mathrm{~V}$ vs. $\mathrm{Li}^{+} / \mathrm{Li}$ while in the homeotype $\mathrm{LiVPO}_{4} \mathrm{O}$, the apparent same $\mathrm{V}^{3+} / \mathrm{V}^{4+}$ redox couple is activated at $2.3 \mathrm{~V}$ vs. $\mathrm{Li}^{+} / \mathrm{Li}$. This large difference cannot be attributed only to the inductive effect, Li site energy or even cation-cation repulsion (i.e., main mechanisms reported to govern the voltage of a given redox couple): it is actually due to the vanadyl distortion observed in $\mathrm{LiVPO}_{4} \mathrm{O}$ and not in $\mathrm{LiVPO}_{4} \mathrm{~F}$. The first order Jahn Teller (FOJT) distortion is known to be weak in $\mathrm{d}^{1}\left(\mathrm{~V}^{4+}\right)$ and $\mathrm{d}^{2}\left(\mathrm{~V}^{3+}\right)$ and even inexistent for $\mathrm{d}^{3}\left(\mathrm{~V}^{2+}\right)$ and $\mathrm{d}^{0}\left(\mathrm{~V}^{5+}\right)$ cations (Figure 2). Therefore, the second order Jahn Teller (SOJT) effect drives the distortion of the $\mathrm{V}^{4+}$ and $\mathrm{V}^{5+}$ polyhedra while this distortion can be prevented for $\mathrm{V}^{4+}$ in a mixed $\mathrm{O}^{2-} / \mathrm{F}^{-}$environment. This wide range of oxidation states for vanadium cations $\left(\mathrm{V}^{2+}, \mathrm{V}^{3+}, \mathrm{V}^{4+}\right.$ and $\left.\mathrm{V}^{5+}\right)$ and the extended panel of environments that they can adopt (regular octahedra, distorted octahedra, square pyramids and tetrahedra) with very different electronic configurations depending on the ligand distribution (JT active or JT inactive) confer to the vanadium phosphate a very rich crystal chemistry. 


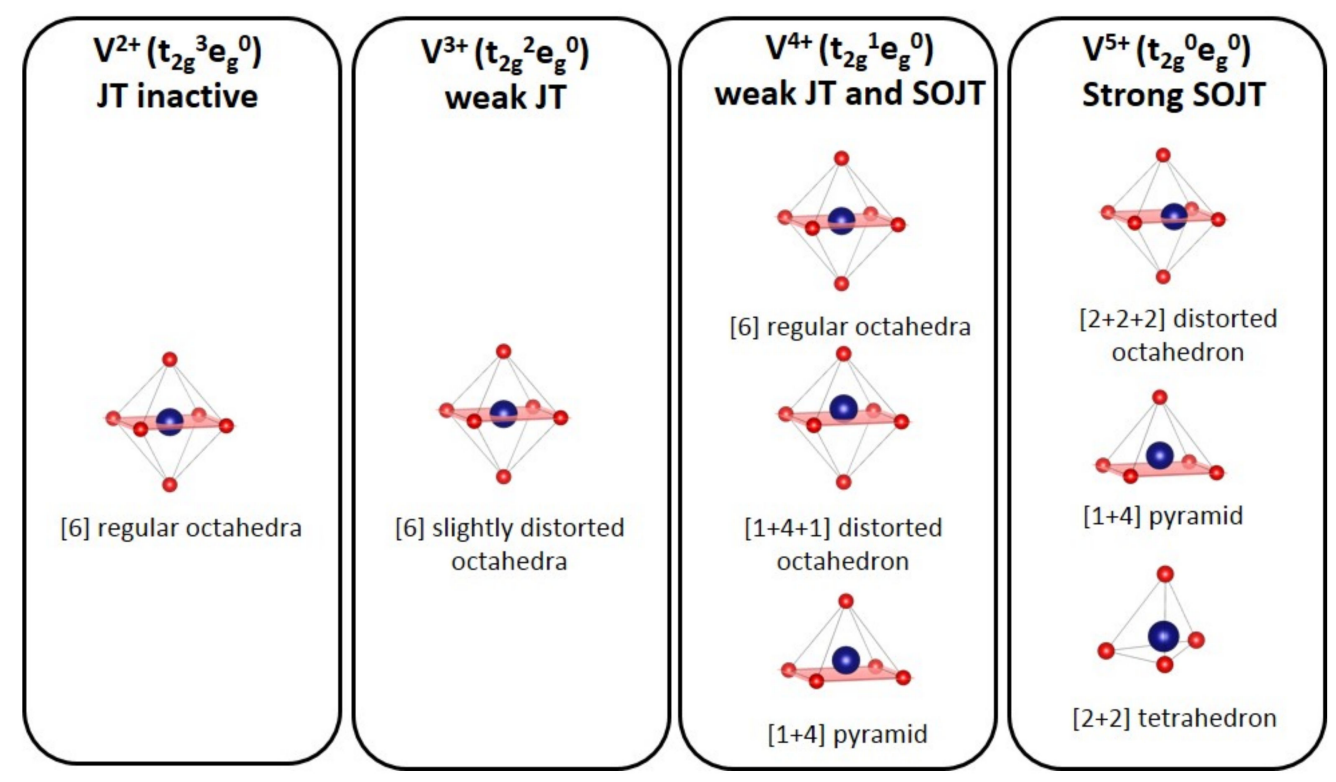

Figure 2. Stable environments of vanadium according to its oxidation state [15]. The number in square brackets correspond to the number of "equivalent bonds".

Beyond their fascinating electrochemical properties, vanadium phosphate materials possess very interesting catalytic and magnetic properties. The relation between structures and these properties was already reviewed by Raveau's group 20 years ago [15] and despite the existence of several reviews on polyanionic structures in Li and Na-ion batteries [16-19], or even specific to vanadyl phosphates (i.e., $\left.\mathrm{A}_{\mathrm{x}}(\mathrm{VO}) \mathrm{PO}_{4}\right)[20,21]$, none of them focused on the relation between electrochemical properties and crystallographic structure in vanadium phosphates. Therefore, this article aims at clarifying this relation in order to unveil the structural features that dictate the redox voltage in such compounds. Through the fine description of the redox mechanism and the structural evolution observed during cycling of some widely studied materials (NASICON Na $3 \mathrm{~V}_{2}\left(\mathrm{PO}_{4}\right)_{3}$, anti-NASICON Li $\mathrm{V}_{2}\left(\mathrm{PO}_{4}\right)_{3}$, $\mathrm{Na}_{3} \mathrm{~V}_{2}\left(\mathrm{PO}_{4}\right)_{2} \mathrm{~F}_{3 \mathrm{x}} \mathrm{O}_{\mathrm{x}}$, and Tavorite-like $\left.\mathrm{LiVPO}_{4} \mathrm{~F}_{1-\mathrm{x}} \mathrm{O}_{\mathrm{x}}\right)$ we propose to sort all the vanadium phosphates reported as positive electrode materials for $\mathrm{Li}$ and $\mathrm{Na}$-ion batteries according to the distribution of phosphate groups around the vanadium polyhedra. This classification gives a holistic picture of such systems and allows for identifying the strategies available to tend towards reversible high-voltage multi-electron reactions in Alkali-ion batteries.

\section{Irreversible Multi-Electron Reactions in NASICON and Anti-NASICON $\mathrm{A}_{\mathbf{x}} \mathbf{V}_{\mathbf{2}}\left(\mathrm{PO}_{4}\right)_{3}(\mathrm{~A}=\mathrm{Li}, \mathrm{Na})$ Structures}

The NASICON (Na-super ionic conductor) and anti-NASICON structures have the general formula $\mathrm{A}_{\mathrm{x}} \mathrm{M}_{2}\left(\mathrm{XO}_{4}\right)_{3}$ (with $\mathrm{M}=\mathrm{Fe}, \mathrm{Ti}, \mathrm{Sc}, \mathrm{Hf}, \mathrm{V}, \mathrm{Ti}, \mathrm{Zr}$, etc. or mixtures of them and $\mathrm{X}=\mathrm{W}, \mathrm{P}, \mathrm{S}, \mathrm{Si}$, Mo or mixtures of them) $[22,23]$. These versatile structures have provided a great playground for solid state chemists. Manthiram and Goodenough demonstrated experimentally the inductive effect which modulates the voltage of the $\mathrm{Fe}^{3+} / \mathrm{Fe}^{2+}$ redox couple in NASICON [24] which is at the origin of all advances on polyanion materials as positive electrode materials for Alkali-ion batteries. The crystallographic arrangements of NASICON and anti-NASICON are closely related. Indeed, they are built on a threedimensional framework of $\mathrm{VO}_{6}$ octahedra sharing all their corners with $\mathrm{PO}_{4}$ tetrahedra and conversely forming basic $\mathrm{V}_{2}\left(\mathrm{PO}_{4}\right)_{3}$ repeating units commonly named "lantern units" (Figure 3). The connectivity of the lantern units generates different ion conduction paths, vanadium environments and hence different electrochemical properties. 

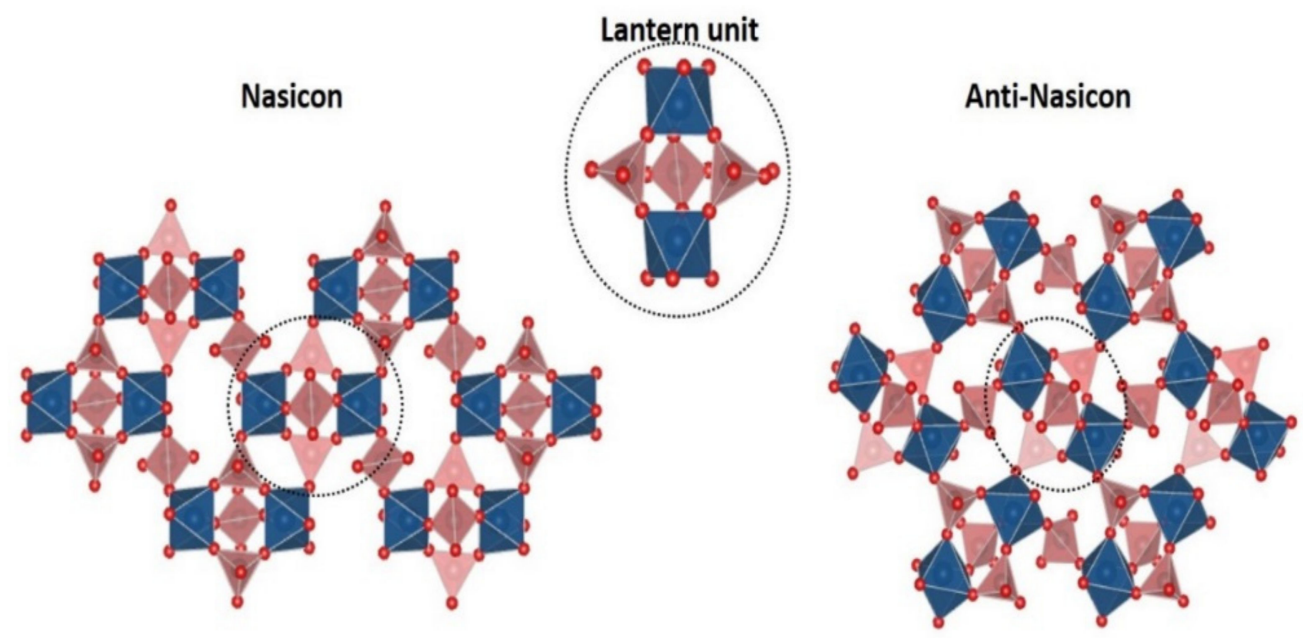

Figure 3. Structural relationship between Nasicon (left) and anti-Nasicon (right) structures adapted from ref. [18].

In the structure of the anti-NASICON polymorph of $\mathrm{Li}_{3} \mathrm{~V}_{2}\left(\mathrm{PO}_{4}\right)_{3}$, the lithium ions fully occupy three crystallographic sites (one tetrahedral $\mathrm{Li}(1) \mathrm{O}_{4}$ and two pseudo tetrahedral $\mathrm{Li}(2) \mathrm{O}_{4} \mathrm{O}$ and $\mathrm{Li}(3) \mathrm{O}_{4} \mathrm{O}$ sites) [25-27]. The electrochemical extraction of lithium from $\mathrm{Li}_{3} \mathrm{~V}_{2}\left(\mathrm{PO}_{4}\right)_{3}$ occurs according to several biphasic reactions involving the $\mathrm{V}^{3+} / \mathrm{V}^{4+}$ redox couple at 3.6, 3.7 and $4.1 \mathrm{~V}$ vs. $\mathrm{Li}^{+} / \mathrm{Li}$ and then the $\mathrm{V}^{4+} / \mathrm{V}^{5+}$ one at $4.5 \mathrm{~V} \mathrm{vs}$. $\mathrm{Li}^{+} / \mathrm{Li}$ (Figure 4).

Nazar and coworkers [27] studied the complex phase diagram involved during lithium extraction from $\mathrm{Li}_{3} \mathrm{~V}_{2}\left(\mathrm{PO}_{4}\right)_{3}$ through X-ray and neutron diffraction (XRD and $\mathrm{ND}$ ) and solid state nuclear magnetic resonance spectroscopy (NMR), as summarized in Figure 5. The first delithiation step leads to the formation of $\mathrm{Li}_{2 \cdot 5} \mathrm{~V}_{2}\left(\mathrm{PO}_{4}\right)_{3}$ with partial depopulation of the pseudo tetrahedral $\left(\mathrm{Li}(3) \mathrm{O}_{4} \mathrm{O}\right)$ site and to a complex short range ordering of $\mathrm{V}^{3+} / \mathrm{V}^{4+}$ cations [28]. The following delithiation stage affects only the remaining $\mathrm{Li}(3)$ ions to yield to $\mathrm{Li}_{2} \mathrm{~V}_{2}\left(\mathrm{PO}_{4}\right)_{3}$ characterized by lithium/vacancies and $\mathrm{V}^{3+} / \mathrm{V}^{4+}$ orderings as suggested by diffraction. The further oxidation of vanadium allows reaching the $\mathrm{V}^{4+}$-rich $\mathrm{LiV}_{2}\left(\mathrm{PO}_{4}\right)_{3}$ phase in which only one $\mathrm{Li}$ site remains $(\mathrm{Li}(2))$ as fully occupied. In this phase, there are two very similar crystallographic sites for vanadium $((\mathrm{V}(1)-\mathrm{O}=\mathrm{V}(2)-\mathrm{O}=1.91 \AA$ in average $)$.
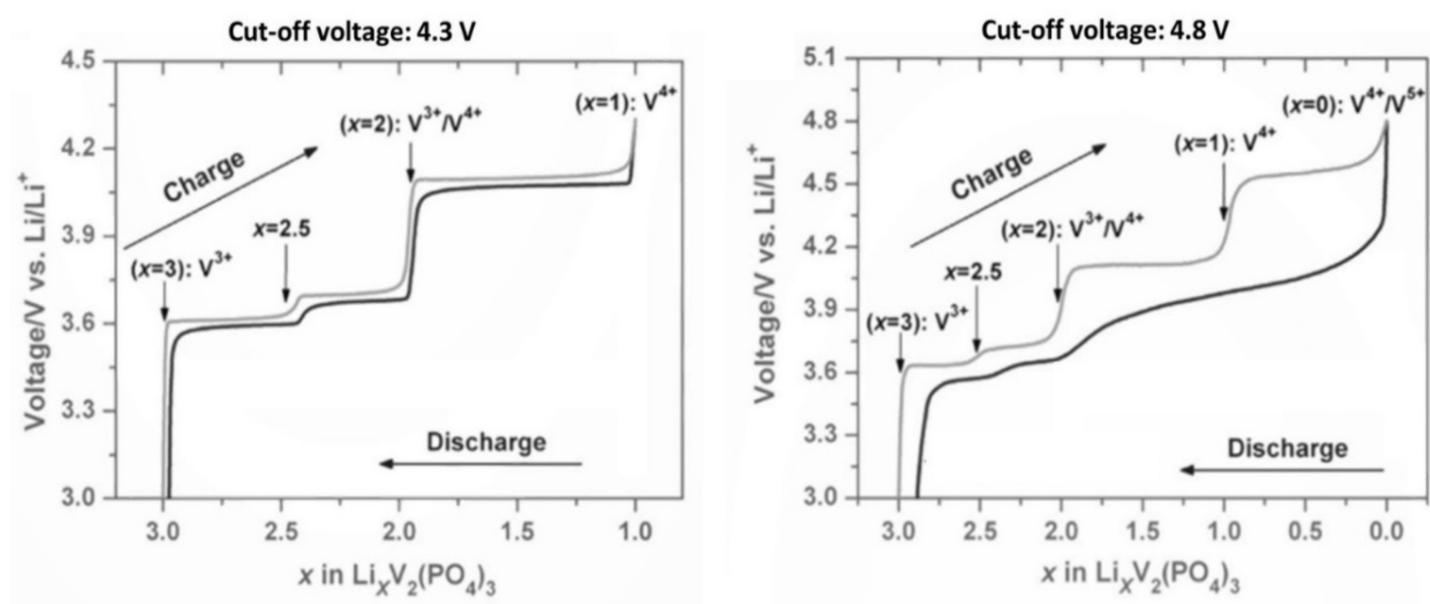

Figure 4. Electrochemical signature of $\mathrm{Li}_{3} \mathrm{~V}_{2}\left(\mathrm{PO}_{4}\right)_{3}$ cycled between (left) 3.0 and $4.3 \mathrm{~V}$ vs. $\mathrm{Li}^{+} / \mathrm{Li}$ or between (right) 3.0 and $4.8 \mathrm{~V}$ vs. $\mathrm{Li}^{+} / \mathrm{Li}$ adapted from ref. [29]. Reproduced with permission from Rui et al., Journal of Power Sources; published by Elsevier, 2014.

The last process leading to the $\mathrm{V}_{2}\left(\mathrm{PO}_{4}\right)_{3}$ composition is kinetically more limited with a large over-potential (around $500 \mathrm{mV}$ ) [27]. At this state of charge, the environments of vanadium (with a mixed valence $\mathrm{V}^{4+} / \mathrm{V}^{5+}$ ) become more distorted, although without 
significant modification compared to the average V-O distances observed in the $\mathrm{V}^{\mathrm{IV}}$-rich $\mathrm{LiV}_{2}\left(\mathrm{PO}_{4}\right)_{3}$ phase. This extraction/insertion process is asymmetrical as the lithium ordering observed for $\mathrm{LiV}_{2}\left(\mathrm{PO}_{4}\right)_{3}$ during charge is not observed during discharge. A disordered Lithium re-intercalation is observed until the $\mathrm{Li}_{2} \mathrm{~V}_{2}\left(\mathrm{PO}_{4}\right)_{3}$ composition is reached [30]. This asymmetrical mechanism is not observed for a lower cut-off voltage (i.e., $4.3 \mathrm{~V}$ when the $\mathrm{V}^{4+} / \mathrm{V}^{5+}$ redox couple is not activated, see Figure 4$)$. Under this electrochemical cycling conditions the charge and discharge superimposes [31]. That was tentatively explained, in ref. [27], by the occurrence of Lithium/vacancies ordering observed in $\mathrm{LiV}_{2}\left(\mathrm{PO}_{4}\right)_{3}$ which involves an ordered depopulation of Lithium, whereas from the disordered fully delithiated phase the lithium is free to be inserted randomly until the $\mathrm{Li}_{2} \mathrm{~V}_{2}\left(\mathrm{PO}_{4}\right)_{3}$ composition is recovered. More recently, operando XAS at V K-edge investigation of this irreversible mechanism suggested the formation of anti-site $\mathrm{Li} / \mathrm{V}$ defects at high voltage (Figure 5) providing $\mathrm{V}^{5+}$ with a much more stable tetrahedral environment than its initial distorted octahedral one [32].

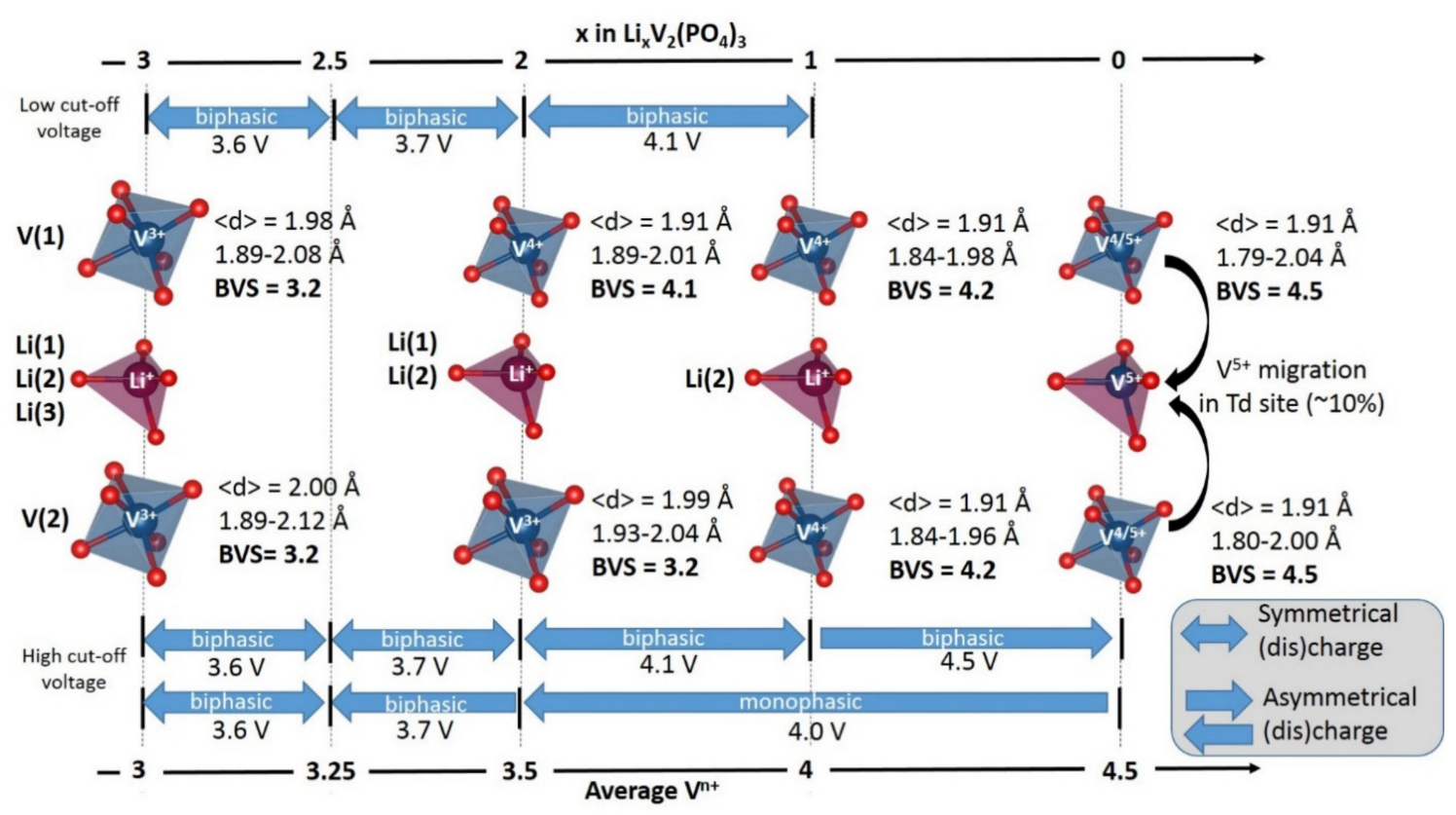

Figure 5. Structural evolution during Lithium extraction/insertion from/into $\mathrm{Li}_{3} \mathrm{~V}_{2}\left(\mathrm{PO}_{4}\right)_{3}[27,32]$.

In $\mathrm{Li}_{3} \mathrm{~V}_{2}\left(\mathrm{PO}_{4}\right)_{3}$, the electronically insulating phosphate groups isolate the valence electrons of transition metals within the lattices resulting in low intrinsic electronic conductivitiesa trend common to all polyanion compounds. Therefore, the use of carbon coating or/and doping elements are required to improve the electrochemical performances: all the works applying these strategies are reviewed in ref [29]. The majority of these studies reports good performances only in the small voltage range (i.e., $3.0-4.3 \mathrm{~V} \mathrm{vs.} \mathrm{Li}^{+} / \mathrm{Li}$, in which only the $\mathrm{V}^{3+} / \mathrm{V}^{4+}$ is activated). Indeed, due to the strong distortion of vanadium environments and the $\mathrm{Li} / \mathrm{V}$ anti-site defects generated, the kinetic limitations of the $\mathrm{V}^{4+} / \mathrm{V}^{5+}$ process is difficult to overcome.

The lithium insertion into $\mathrm{Li}_{3} \mathrm{~V}_{2}\left(\mathrm{PO}_{4}\right)_{3}$ reveals a complex series of reactions as well, to reach $\mathrm{Li}_{5} \mathrm{~V}_{2}\left(\mathrm{PO}_{4}\right)_{3}$ by activating the $\mathrm{V}^{2+} / \mathrm{V}^{3+}$ redox couple [33]. The whole lithium insertion process into $\mathrm{Li}_{3+\mathrm{x}} \mathrm{V}_{2}\left(\mathrm{PO}_{4}\right)_{3}$ involves four consecutive two-phase regions to reach $\mathrm{Li}_{5} \mathrm{~V}_{2}\left(\mathrm{PO}_{4}\right)_{3}$. Approximately $0.5 \mathrm{Li}^{+}$is inserted at every potential plateau around $1.95,1.86$, 1.74 and $1.66 \mathrm{~V}$ vs. $\mathrm{Li}^{+} / \mathrm{Li}[26]$. To the best of our knowledge, the crystallographic details of this complex mechanism have never been fully studied yet.

The anti-NASICON polymorph of $\mathrm{Li}_{3} \mathrm{~V}_{2}\left(\mathrm{PO}_{4}\right)_{3}$ is most thermodynamically stable but Gaubicher et al. [34] obtained the NASICON form by $\mathrm{Na}^{+} / \mathrm{Li}^{+}$ionic exchange from $\mathrm{Na}_{3} \mathrm{~V}_{2}\left(\mathrm{PO}_{4}\right)_{3}$. This material reveals a similar electrochemical signature compared to the 
one of $\mathrm{Na}_{3} \mathrm{~V}_{2}\left(\mathrm{PO}_{4}\right)_{3}$ with a single plateau until the $\mathrm{LiV}_{2}\left(\mathrm{PO}_{4}\right)_{3}$ composition at $3.7 \mathrm{~V}$ vs. $\mathrm{Li}^{+} / \mathrm{Li}$. The crystal structure of $\mathrm{Na}_{3} \mathrm{~V}_{2}\left(\mathrm{PO}_{4}\right)_{3}$ was originally reported by Delmas et al. [35] 40 years ago using the standard rhombohedral unit cell, S.G. $R$ - $3 c$. Since then, $\mathrm{Na}_{3} \mathrm{~V}_{2}\left(\mathrm{PO}_{4}\right)_{3}$ has almost always been reported to adopt the rhombohedral symmetry with a partial occupancy of both $\mathrm{Na}(1)$ ( $6 \mathrm{~b}$ Wyckoff position) and $\mathrm{Na}(2)$ (18e Wyckoff position) sodium sites. However, a recent article reveals that a $C 2 / c$ space group is more appropriate to describe this structure at room temperature and below due to Sodium-vacancies ordering [36] within five sites (one $4 a$ and four others $8 f$ ) fully occupied. Several transitions between 10 and $230{ }^{\circ} \mathrm{C}$ involving four distinct phases ( $\alpha$ ordered, $\beta$ and $\beta^{\prime}$ with incommensurate modulations and $\gamma$ disordered) were also reported. The transition between the $\alpha$ and $\beta$ forms occurring close to the ambient temperature (i.e., $27^{\circ} \mathrm{C}$ ) may impact the sodium diffusion and a fortiori the electrochemical performances while the vanadium environment is hardly impacted by this phase transition. In both cases the $\mathrm{VO}_{6}$ entities are slightly distorted with distances ranging between 1.97 and $2.03 \AA$ for the rhombohedral description ( $2.00 \AA$ in average on a single vanadium site) or 1.94 and $2.06 \AA$ for the monoclinic one ( $2.00 \AA$ in average on the three vanadium sites).

The electrochemical sodium extraction from $\mathrm{Na}_{3} \mathrm{~V}_{2}\left(\mathrm{PO}_{4}\right)_{3}$ occurs at a $3.4 \mathrm{~V}$ vs. $\mathrm{Na}^{+} / \mathrm{Na}$ according to a biphasic reaction until the $\mathrm{NaV}_{2}\left(\mathrm{PO}_{4}\right)_{3}$ composition is reached (Figure 6). The structure of this $\mathrm{V}^{4+}$ phase, reported by Jian et al. [37], keeps a NASICON framework (Rhombohedral, $R \overline{3} c$ ) with only one fully occupied sodium site ( $6 b$ Wyckoff site). During the sodium extraction, the $\mathrm{V}-\mathrm{O}$ distances in $\mathrm{VO}_{6}$ octahedra undergo an inequivalent shortening leading to distorted $\mathrm{VO}_{6}$ octahedra (with $3 \mathrm{~V}$-O distances at $1.86 \AA$ and three others at $1.95 \AA$ ). The electrochemical extraction of the third sodium has never been reported despite the apparent successful chemical extraction realized by Gopalakrishnan et al. [38]. However, they did not report the detailed structure of this mixed-valence $\mathrm{V}_{2}\left(\mathrm{PO}_{4}\right)_{3}$.
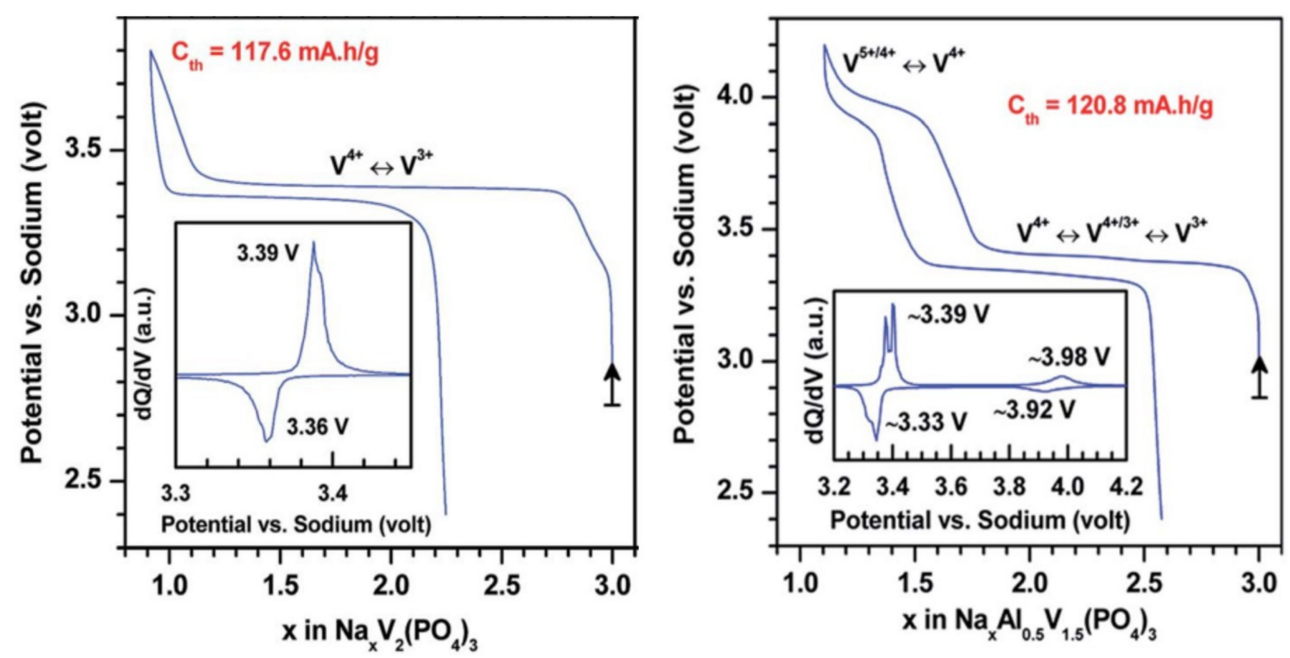

Figure 6. High voltage signature of Nasicon $\mathrm{Na}_{3} \mathrm{~V}_{2}\left(\mathrm{PO}_{4}\right)_{3}$ and $\mathrm{Na}_{3} \mathrm{~V}_{1.5} \mathrm{Al}_{0.5}\left(\mathrm{PO}_{4}\right)_{3}$, adapted from ref. [39]. Reproduced from Ref. [39] with permission from the Centre National de la Recherche Scientifique (CNRS) and The Royal Society of Chemistry.

Even though the third $\mathrm{Na}^{+}$of $\mathrm{Na}_{3} \mathrm{~V}_{2}\left(\mathrm{PO}_{4}\right)_{3}$ doesn't seem electrochemically removable, the $\mathrm{V}^{4+} / \mathrm{V}^{5+}$ redox couple in the NASICON was reported to lie at around $4 \mathrm{~V} \mathrm{vs.} \mathrm{Na}^{+} / \mathrm{Na}$ thanks to the partial substitution of a part of Vanadium by Aluminum [39], Iron [40] or Chromium [41]. The Aluminum substituted material presents two advantages as it allows an increase in the capacity due to the lower weight of aluminum compared to vanadium (and also iron and chromium) as well as to reach the mixed valence $\mathrm{V}^{4+} / \mathrm{V}^{5+}$ state at rather high voltage (i.e., $4.0 \mathrm{~V}$ vs. $\mathrm{Na}^{+} / \mathrm{Na}$, see Figure 6). However, in the $\mathrm{Al}^{3+}$ substituted compound, the $\mathrm{V}^{4+} / \mathrm{V}^{5+}$ capacity is limited contrarily to that observed in $\mathrm{Na}_{3} \mathrm{VCr}\left(\mathrm{PO}_{4}\right)_{3}$ where nearly 1.5 electrons/vanadium are exchanged [42]. At room temperature, this redox process induces a rapid degradation of the performance due to the migration of vanadium 
into the vacant $\mathrm{Na}$ site, while at lower temperature (i.e., $-15^{\circ} \mathrm{C}$ ), vanadium is pinned in its original position leading to a rather reversible process is observed [43]. The $\mathrm{V}^{4+} / \mathrm{V}^{5+}$ redox couple has also been reported in Na-rich NASICON such as $\mathrm{Na}_{4} \mathrm{MnV}\left(\mathrm{PO}_{4}\right)_{3}$ [44-47]. From this compound, ca. $3 \mathrm{Na}^{+}$are exchanged based on the $\mathrm{V}^{3+} / \mathrm{V}^{4+}, \mathrm{Mn}^{2+} / \mathrm{Mn}^{3+}$ and then $\mathrm{V}^{4+} / \mathrm{V}^{5+}$ redox achieving a capacity of $155 \mathrm{mAh} / \mathrm{g}$. However, this latter appears to be poorly reversible inducing a higher irreversible capacity upon discharge during which the highly polarized S-shape voltage profile contrasts with staircase charge curve [45-47].

The replacement of a $\left(\mathrm{PO}_{4}\right)^{3-}$ group in $\mathrm{Na}_{3} \mathrm{~V}_{2}\left(\mathrm{PO}_{4}\right)_{3}$ by $3 \mathrm{~F}^{-}$leads to the $\mathrm{Na}_{3} \mathrm{~V}_{2}\left(\mathrm{PO}_{4}\right)_{2} \mathrm{~F}_{3}$ composition, often named as a "NASICON composition" but its crystal structure is fundamentally different.

\section{Irreversible Multi-Electron Reactions in $\mathrm{Na}_{3} \mathrm{~V}_{2}\left(\mathrm{PO}_{4}\right)_{2} \mathrm{~F}_{3}$}

The first physico-chemical investigation of the $\mathrm{Na}_{3} \mathrm{M}_{2}\left(\mathrm{PO}_{4}\right)_{2} \mathrm{~F}_{3}$ system was conducted 20 years ago by Le Meins et al. [48]. They demonstrated a great compositional tunability of this framework which can accommodate many trivalent cations in octahedral sites $(\mathrm{M}=\mathrm{Al}$, $\mathrm{V}, \mathrm{Cr}, \mathrm{Fe}$ and $\mathrm{Ga}$ ) and proposed the description of the structure of the vanadium phase in the $\mathrm{P} 4_{2} / \mathrm{mnm}$ space group. Later, a combined synchrotron $\mathrm{X}$-ray and neutron diffraction investigation revealed a tiny orthorhombic distortion at room temperature [49].

The Amam space group (i.e., S.G. \#63, C mcm) used leads to a different sodium distribution in the cell with three Na sites, one $4 c$ fully occupied and two $8 f$ partially occupied (approximatively distributed as 1/3:2/3) (Figure 7). The host structure is composed of $\mathrm{V}_{2} \mathrm{O}_{8} \mathrm{~F}_{3}$ bi-octahedra sharing a fluorine aligned along the [001] direction and connected to each other through $\mathrm{PO}_{4}$ tetrahedra aligned in parallel with the (001) plane (Figure 7). The $\mathrm{VO}_{4} \mathrm{~F}_{2}$ octahedra in this structure are non-centrosymmetric and hence vanadium does not occupy the inversion center. Indeed, a displacement along the c direction leads to two slightly different V-F bonds $(\mathrm{V}-\mathrm{F}(1)=1.968(6) \AA$ and $\mathrm{V}-\mathrm{F}(2)=1.981(2) \AA$ ).

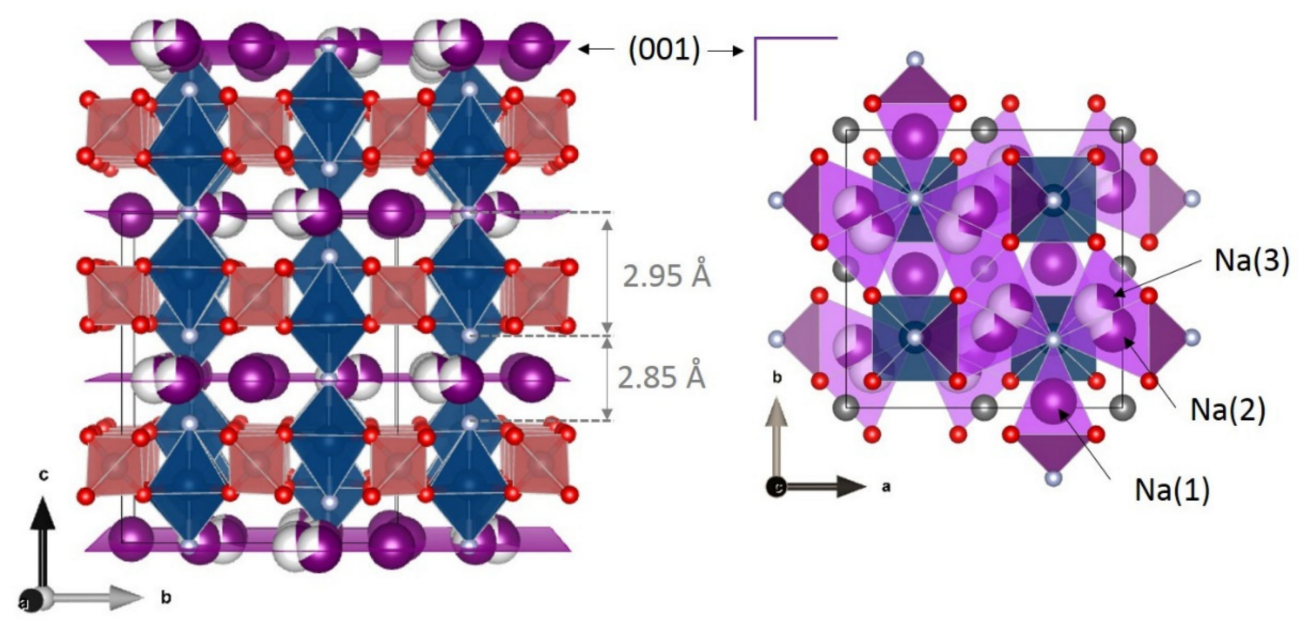

Figure 7. Structure of $\mathrm{Na}_{3} \mathrm{~V}_{2}\left(\mathrm{PO}_{4}\right)_{2} \mathrm{~F}_{3}$ (left) and sodium distribution (right) [49].

Slow electrochemical galvanostatic cycling shows the presence of four distinct reversible voltage-composition features at 3.70, 3.73, 4.18 and $4.20 \mathrm{~V}$ vs. $\mathrm{Na}^{+} / \mathrm{Na}$ (Figure 8) suggesting a complex phase diagram upon sodium extraction/reinsertion [50]. 


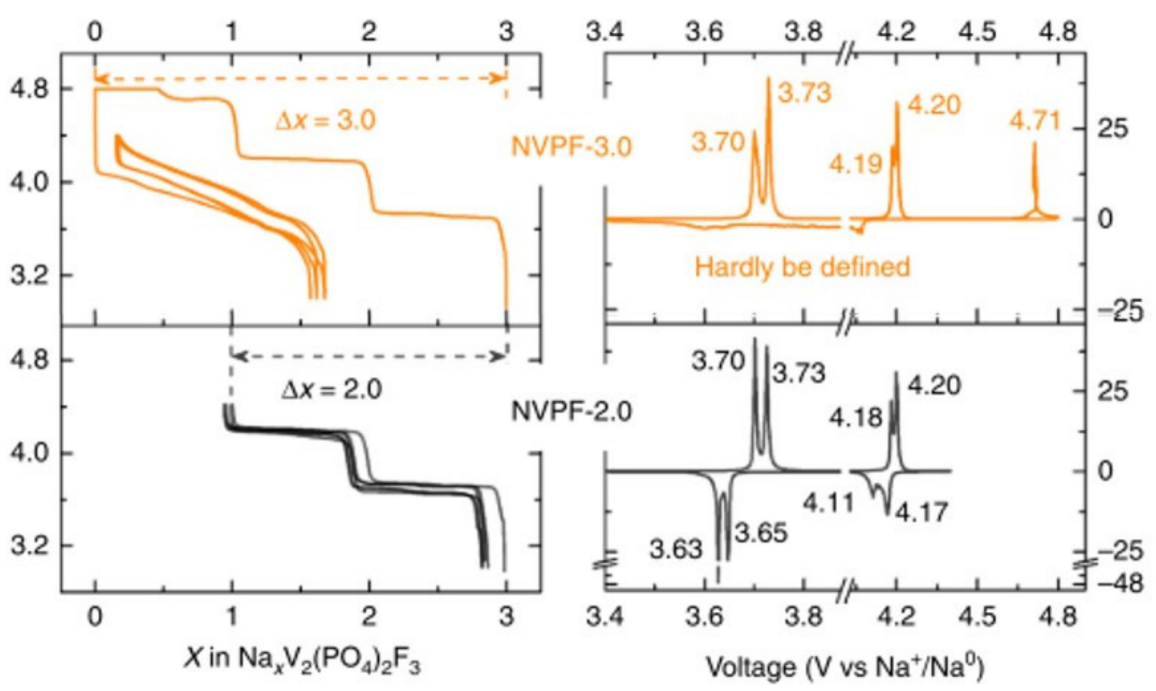

Figure 8. Galvanostatic electrochemical voltage-composition data of $\mathrm{Na}_{3} \mathrm{~V}_{2}\left(\mathrm{PO}_{4}\right)_{2} \mathrm{~F}_{3}$ at $\mathrm{C} / 10$ per exchanged ion and the corresponding derivative curve in the $3.0-4.4 \mathrm{~V}$ or 3.0-4.8 $\mathrm{V}$ voltage range adapted from ref. [51]. Reproduced with permission from Guochan Yan et al., Nature Communications; published by Springer Nature, 2019.

The operando synchrotron XRD investigation conducted by Bianchini et al. [52] is summarized in Figure 9. The phase diagram involves several intermediate phases of compositions $\mathrm{Na}_{\mathrm{x}} \mathrm{V}_{2}\left(\mathrm{PO}_{4}\right)_{2} \mathrm{~F}_{3}$ with $\mathrm{x}=2.4,2.2,2,1.8$ and 1.3 before the $\mathrm{NaV}_{2}\left(\mathrm{PO}_{4}\right)_{2} \mathrm{~F}_{3}$ is reached. During extraction of the first sodium, an alternation between ordered and disordered phases $\left(\mathrm{Na}^{+} /\right.$vacancy and/or $\mathrm{V}^{3+} / \mathrm{V}^{4+}$ ordering and disordering) is observed. The superstructure peaks observed for the $\mathrm{Na}_{2.4} \mathrm{~V}_{2}\left(\mathrm{PO}_{4}\right)_{2} \mathrm{~F}_{3}$ disappear for $\mathrm{Na}_{2.2} \mathrm{~V}_{2}\left(\mathrm{PO}_{4}\right)_{2} \mathrm{~F}_{3}$ and the diffraction pattern of $\mathrm{Na}_{2} \mathrm{~V}_{2}\left(\mathrm{PO}_{4}\right)_{2} \mathrm{~F}_{3}$ reveals the reappearance of a series of additional contributions non-indexed in the tetragonal cell. In the $\mathrm{V}^{3+}$-rich phase, the two symmetrically inequivalent V-F bonds are very similar and as the oxidation of vanadium is increased, two kinds of bonds gradually appear as a short one at $1.88 \AA$ and a longer one at $1.94 \AA$, whereas the equatorial V-O bonds decrease uniformly (from 1.99 to $1.95 \AA$ ). The extraction of the second sodium also involves intermediate phases at $x=1.8$ and $\mathrm{x}=1.3$ accompanied by the disappearance of the superstructure peaks and finally leads to the formation of $\mathrm{NaV}_{2}\left(\mathrm{PO}_{4}\right)_{2} \mathrm{~F}_{3}$. This phase contains a single $\mathrm{Na}$ site and two vanadium sites conferring to vanadium cations two very different environments despite an average oxidation state of $\mathrm{V}^{4+}$. Indeed, the BVS calculation suggests the formation of a $\mathrm{V}^{3+}-\mathrm{V}^{5+}$ pair in bi-octahedra at this composition (Figure 9). The investigation of the redox mechanism involved during sodium extraction was conducted by Broux et al. [53] through operando XANES at V K-edge. They evidenced that $\mathrm{V}^{4+}$ starts to disproportionate from $\mathrm{Na}_{2} \mathrm{~V}_{2}\left(\mathrm{PO}_{4}\right)_{2} \mathrm{~F}_{3}$ and hence the formation of $\mathrm{V}^{3+}-\mathrm{V}^{5+}$ pairs are confirmed for $\mathrm{Na}_{1} \mathrm{~V}_{2}\left(\mathrm{PO}_{4}\right)_{2} \mathrm{~F}_{3}$. 


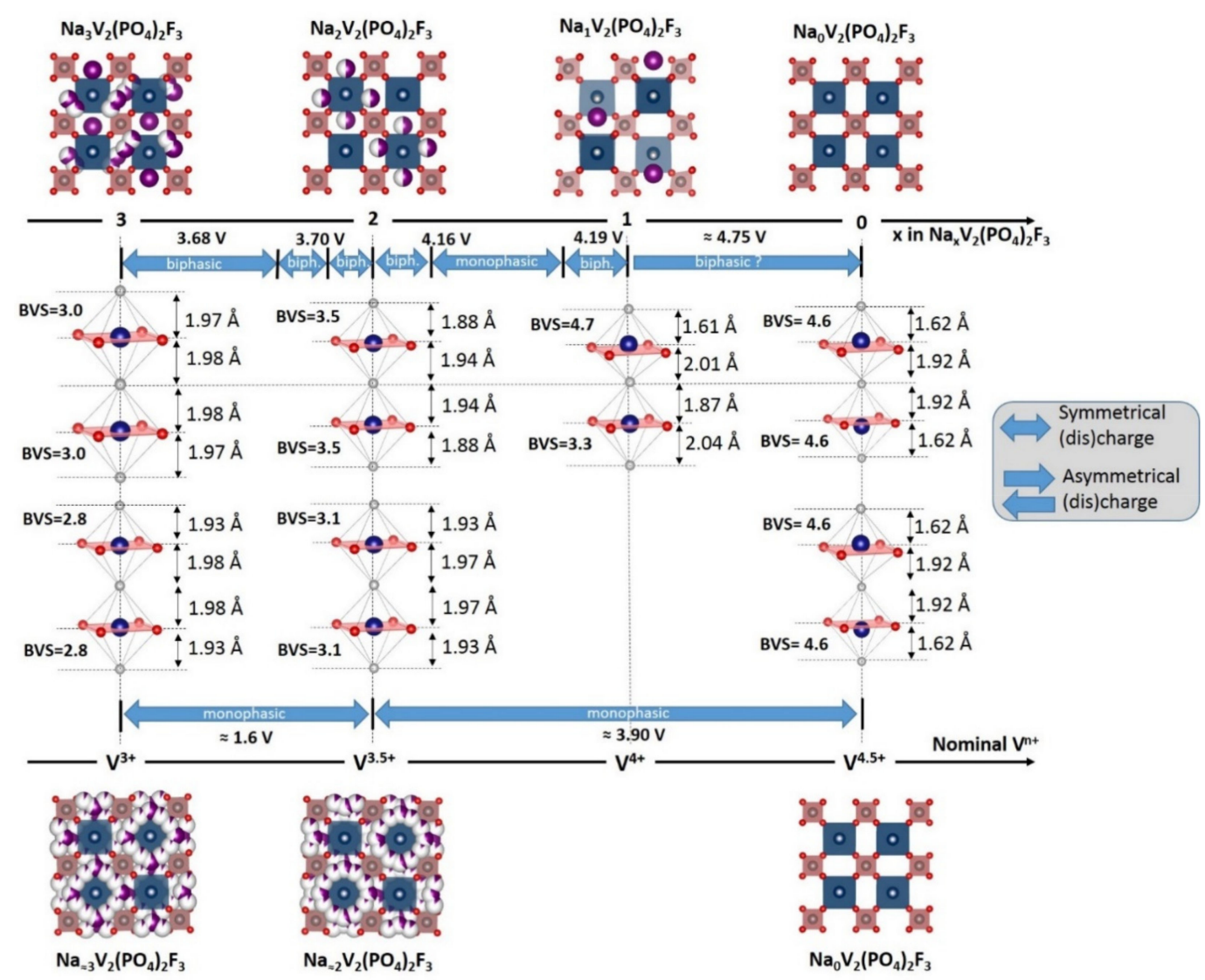

Figure 9. Evolution of vanadium environments and $\mathrm{Na}$ /vacancies ordering upon cycling of $\mathrm{Na}_{3} \mathrm{~V}_{2}\left(\mathrm{PO}_{4}\right)_{2} \mathrm{~F}_{3}[51,52,54]$.

Kang and coworkers predicted that the extraction of the third $\mathrm{Na}^{+}$towards the mixed valence $\mathrm{V}^{4+} / \mathrm{V}^{5+} \mathrm{V}_{2}\left(\mathrm{PO}_{4}\right)_{2} \mathrm{~F}_{3}$ composition would occur only at very high voltage (ca. $4.9 \mathrm{~V}$ vs. $\mathrm{Na}^{+} / \mathrm{Na}$ ) [55]. This was confirmed experimentally by Tarascon's group, under sever oxidative conditions (i.e., potentiostatic step at $4.8 \mathrm{~V}$ vs. $\mathrm{Na}^{+} / \mathrm{Na}$ see Figure 8 ) in an optimized electrolyte [51]. In this structure, vanadium is displaced from the inversion center of the $\mathrm{VO}_{4} \mathrm{~F}_{2}$ octahedra in such a way as to generate a short $1.62 \AA$ and a longer $1.92 \AA$ $\mathrm{V}-\mathrm{F}$ bond lengths within the bi-octahedra. However, these extreme cycling conditions imply an irreversible reaction and only $2 \mathrm{Na}^{+}$could be reinserted upon discharge down to $3.0 \mathrm{~V}$, according to a solid solution mechanism, the third $\mathrm{Na}^{+}$being reinserted at much lower voltage (i.e., $1.6 \mathrm{~V}$ vs. $3.7 \mathrm{~V}$ for the same composition range upon charge). The subsequent charge/discharge allows for the reversible extraction/insertion of $3 \mathrm{Na}^{+}$in a wide voltage range (1.0-4.4 $\mathrm{V}$ vs. $\left.\mathrm{Na}^{+} / \mathrm{Na}\right)$. This new $\beta-\mathrm{Na}_{3} \mathrm{~V}_{2}\left(\mathrm{PO}_{4}\right)_{2} \mathrm{~F}_{3}$ polymorph exhibits a different symmetry, different $\mathrm{V}-\mathrm{X}$ bond lengths and a disordered Na distribution (see Figure 9) which bears strong resemblance with the one of the high temperature phase $(\mathrm{T}>400$ K) $[49,54]$. Due to the low voltage associated to the reinsertion of third $\mathrm{Na}^{+}$, only $2 \mathrm{Na}^{+}$ can be exchanged in a real battery system where the third one acts as an alkali reservoir to compensate for the solid electrolyte interface (SEI) formation at negative electrode [51], which allows offering up to $460 \mathrm{Wh} / \mathrm{kg}$ in full cell vs. hard carbon $(+18 \%$ compared with a conventional $\left.\alpha-\mathrm{Na}_{3} \mathrm{~V}_{2}\left(\mathrm{PO}_{4}\right)_{2} \mathrm{~F}_{3}\right)$, corresponding to the highest energy density reported so far in Na-ion battery [56].

Most of the $\mathrm{Na}_{3} \mathrm{~V}_{2}\left(\mathrm{PO}_{4}\right)_{2} \mathrm{~F}_{3}$ materials reported as stoichiometric in the literature actually present various amounts of vanadyl-type defects (i.e., partial substitution of $\mathrm{F}^{-}$ by $\mathrm{O}^{2-}$ with a charge compensation by partial oxidation of $\mathrm{V}^{3+}-\mathrm{F}$ into vanadyl $\mathrm{V}^{4+}=\mathrm{O}$ ) impacting on the electrochemical performance. Several authors studied in detail the crystallographic changes generated by this substitution in $\mathrm{Na}_{3} \mathrm{~V}_{2}\left(\mathrm{PO}_{4}\right)_{2} \mathrm{~F}_{3-x} \mathrm{O}_{\mathrm{x}}$ (with $0 \leq \mathrm{x} \leq 0.5[54], 0 \leq \mathrm{x} \leq 2$ [55] and $\mathrm{x}=1.6[57,58])$. This oxidation has strong effects on the local environments of vanadium and on the sodium distribution and appears to 
be beneficial for enhancing the charge rates of the battery. Kang's group [57] was the first to investigate the performance of $\mathrm{Na}_{3} \mathrm{~V}_{2}\left(\mathrm{PO}_{4}\right)_{2} \mathrm{~F}_{1.4} \mathrm{O}_{1.6}$ (i.e., $\mathrm{V}^{3.8+}$ ) as a positive electrode material and reported high charge and discharge rate capabilities, assigned to a low activation energy for $\mathrm{Na}^{+}$diffusion $(\sim 350 \mathrm{meV})$ inside the framework, despite the poor electronic conductivity $\left(\sim 2.4 \times 10^{-12} \mathrm{~S} . \mathrm{cm}^{-1}\right)$ and its great cycling stability was assigned to the small volume change during sodium extraction/insertion $(\sim 3 \%)$. The same group later published a promising result about the computed voltage for the extraction of the third sodium around $4.7 \mathrm{~V}$ for $\mathrm{Na}_{3} \mathrm{~V}_{2}\left(\mathrm{PO}_{4}\right)_{2} \mathrm{~F}_{1.5} \mathrm{O}_{1.5}$ [55] (lower than the one computed up to $4.9 \mathrm{~V}$ in $\left.\mathrm{Na}_{3} \mathrm{~V}_{2}\left(\mathrm{PO}_{4}\right)_{2} \mathrm{~F}_{3}\right)$ and experimentally realized the reversible exchange of more than one electron per vanadium at high voltage (ca. $3.8 \mathrm{~V} \mathrm{vs.} \mathrm{Na}^{+} / \mathrm{Na}$ in average) with a symmetrical charge/discharge profile and an improved capacity retention.

\section{Low Voltage Multi-Electron Reactions in Tavorites $\mathrm{Li}_{x} \mathrm{VPO}_{4} \mathrm{Y}(\mathrm{Y}=\mathrm{O}, \mathrm{F}$ and/or $\mathrm{OH})$}

Tavorite-type compositions of general formula $\mathrm{A}_{\mathrm{x}} \mathrm{MXO}_{4} \mathrm{Y}$ are a third class of very interesting polyanion structures in which $\mathrm{A}$ is an alkali cation (i.e., $\mathrm{Li}, \mathrm{Na}$ and $0 \leq \mathrm{x} \leq 2$ ) and $\mathrm{M}$ a metal (i.e., $\mathrm{Mg}, \mathrm{Al}, \mathrm{Ti}, \mathrm{V}, \mathrm{Fe}, \mathrm{Mn}, \mathrm{Zn}$ or mixture of them). The polyanionic group, $\mathrm{XO}_{4}$, is either $\mathrm{PO}_{4}$ or $\mathrm{SO}_{4}$ and the bridging anion, $\mathrm{Y}$, is a halide, hydroxide, oxygen, $\mathrm{H}_{2} \mathrm{O}$ group or a mixture of them [18]. The multiple redox center combined with this double inductive effect bring a strong interest at both practical and fundamental levels as it allows scanning a wide range of working voltages, from $1.5 \mathrm{~V}$ for $\mathrm{Ti}^{3+} / \mathrm{Ti}^{4+}$ in $\mathrm{LiTiPO}_{4} \mathrm{O}$ [59] to $4.26 \mathrm{~V}$ for the $\mathrm{V}^{3+} / \mathrm{V}^{4+}$ redox couple in $\mathrm{LiVPO}_{4} \mathrm{~F}$ [60]. The high voltages provided by the $\mathrm{V}^{3+} / \mathrm{V}^{4+}$ and $\mathrm{V}^{4+} / \mathrm{V}^{5+}$ redox couples confer high theoretical energy densities to the vanadium-based Tavorite compositions.

The crystal structure of Tavorite-like materials can be described in either triclinic $(P-1$, with $Z=2$ or $Z=4)$ or monoclinic $(C 2 / c$ or $P 21 / c)$ systems $[14,61,62]$. Tavoritelike therefore gathers Tavorite $\left(P-1, \mathrm{Z}=2, \mathrm{LiVPO}_{4} \mathrm{~F}\right.$ and $\left.\mathrm{LiVPO}_{4} \mathrm{OH}\right)$, Montebrasite $(P-1$, $\left.\mathrm{Z}=4, \mathrm{LiVPO}_{4} \mathrm{O}\right)$, Maxwellite $\left(\mathrm{C} 2 / c, \mathrm{NaVPO}_{4} \mathrm{~F}\right.$ and $\left.\mathrm{HVPO}_{4} . \mathrm{OH}\right)$ and even Talisite $\left(P 2_{1} / c\right.$, $\mathrm{NaVPO}_{4} \mathrm{O}$ ) structures. Their crystallographic arrangements present common features which can be broadly described as vanadium octahedra $\left(\mathrm{VO}_{4} \mathrm{Y}_{2}\right)$ sharing a bridging anion $\mathrm{Y}$ in order to form infinite chains $\left[-\mathrm{Y}-\mathrm{VO}_{4}-\mathrm{Y}-\right]_{\infty}$. These chains are connected to each other through $\mathrm{PO}_{4}$ tetrahedra sharing their four oxygen atoms with four vanadium octahedra belonging to three different chains. This 3D framework accommodates $\mathrm{Li}^{+}$or $\mathrm{Na}^{+}$in hexagonal channels. The symmetry of vanadium octahedra is dictated by the nature of the $\mathrm{V}^{\mathrm{n}+}-\mathrm{Y}$ bond. Indeed, in $\mathrm{V}^{3+}$-rich $\mathrm{LiVPO}_{4} \mathrm{~F}, \mathrm{NaVPO}_{4} \mathrm{~F}$ and $\mathrm{VPO}_{4} \cdot \mathrm{H}_{2} \mathrm{O}$, the vanadium is located on an inversion center of the $\mathrm{VO}_{4} \mathrm{Y}_{2}$ octahedra, whereas in $\mathrm{V}^{4+}$-rich $\mathrm{NaVPO}_{4} \mathrm{O}$ and $\mathrm{LiVPO}_{4} \mathrm{O}$ a loss of the centrosymmetry of the vanadium environment is observed. Indeed, in the Tavorite-like structure, for an oxidation state of vanadium superior to +3 , vanadium likely forms the vanadyl bond resulting from the Jahn Teller activity of $\mathrm{V}^{4+}$ $\left(\mathrm{d}^{1} \mathrm{t} 2 \mathrm{~g}^{1} \mathrm{eg}^{0}\right)$. This strongly covalent $\mathrm{V}=\mathrm{O}$ bond can be formed only with oxygen atoms which are not already involved in a covalent $\mathrm{PO}_{4}$ group. Only the bridging oxygen, $\mathrm{Y}$, fulfils these requirements and, therefore, in the $\mathrm{V}^{4+}$ compounds, an ordering between short and long bonds takes place along the chains (Figure 10). This ordering generates a change of space group (from $\mathrm{C} 2 / \mathrm{c}$ for $\mathrm{NaVPO}_{4} \mathrm{~F}$ to $\mathrm{P}_{1} / \mathrm{c}$ for $\mathrm{NaVPO}_{4} \mathrm{O}$ ) or a doubling of the cell size $\left(\mathrm{Z}=2\right.$ for $\mathrm{LiVPO}_{4} \mathrm{~F}$ to $\mathrm{Z}=4$ for $\left.\mathrm{LiVPO}_{4} \mathrm{O}\right)$.

The lithium content in $\mathrm{Li}_{\mathrm{x}} \mathrm{VPO}_{4} \mathrm{O}$ can vary from 0 to 2, leading to a capacity of $300 \mathrm{mAh} / \mathrm{g}$ at an average voltage of ca. $3.1 \mathrm{~V}$ allowing the achievement a stable energy density $>900 \mathrm{Wh} / \mathrm{kg}$ using surface engineering and nanosizing strategies [9-13]. However, the large difference between the voltage for oxidation of $\mathrm{V}^{4+}$ into $\mathrm{V}^{5+}$ (i.e., $3.95 \mathrm{~V} \mathrm{vs.} \mathrm{Li}^{+} / \mathrm{Li}$ ) and that for the reduction in $\mathrm{V}^{4+}$ to $\mathrm{V}^{3+}$ (around $2.3 \mathrm{~V} \mathrm{vs}$. $\mathrm{Li}^{+} / \mathrm{Li}$ ) makes this multi-electron reaction unsuitable for a real battery system (Figure 11). 


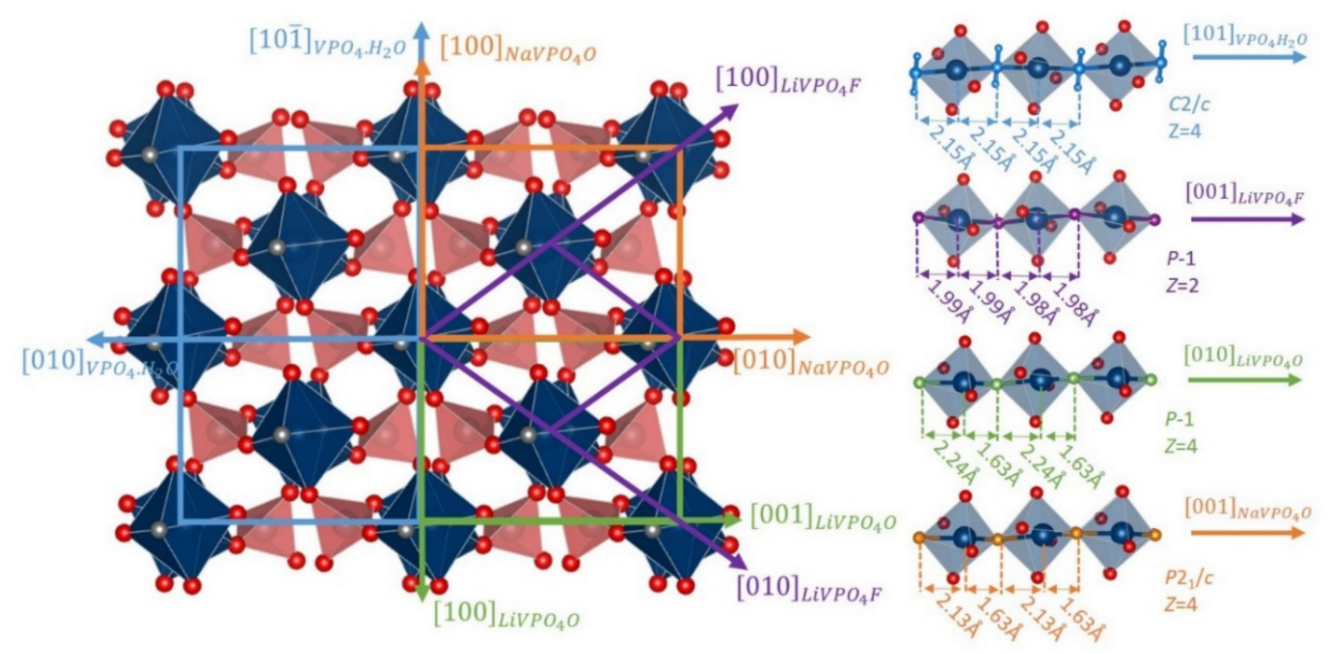

Figure 10. Structural relationships between different Tavorite-type materials.
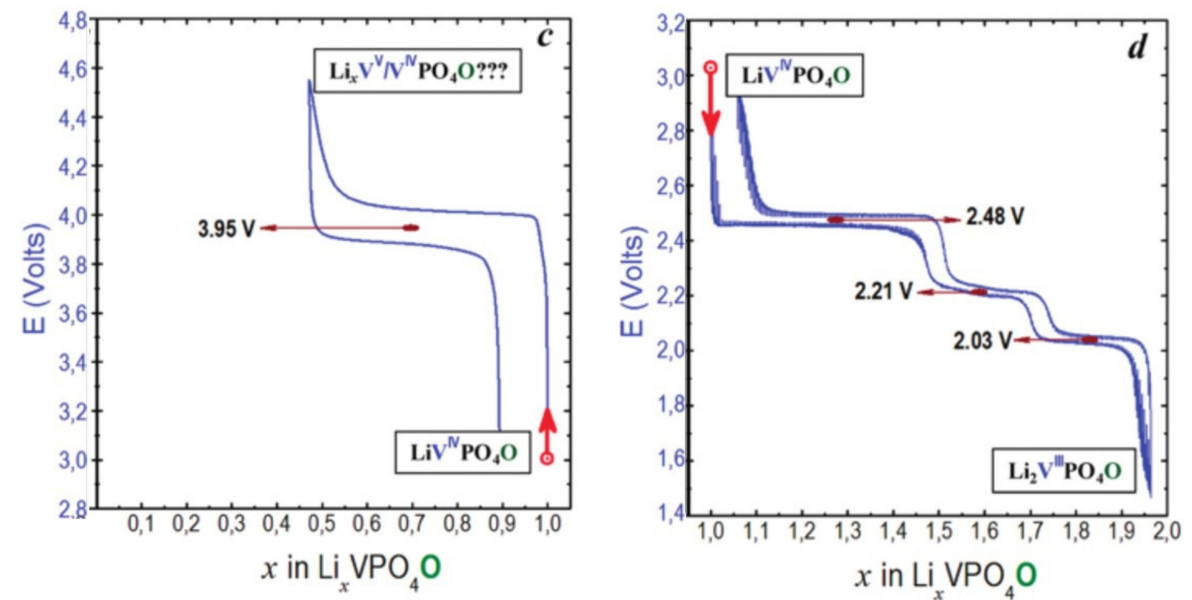

Figure 11. Voltage profile of $\mathrm{Li}_{\mathrm{x}} \mathrm{VPO}_{4} \mathrm{O}$ cycled between 3.0-4.6 V vs. $\mathrm{Li}^{+} / \mathrm{Li}$ (left) and between 3.0 and $1.5 \mathrm{~V}$ vs. $\mathrm{Li}^{+} / \mathrm{Li}$ in GITT mode (right) adapted from ref. [14]. Reproduced with permission from Ateba Mba et al., Chemistry of Materials; published by American Chemical Society, 2012.

In the high voltage region (i.e., $3.0-4.6 \mathrm{~V}$ vs. $\mathrm{Li}^{+} / \mathrm{Li}$ involving the $\mathrm{V}^{4+} / \mathrm{V}^{5+}$ redox couple), the oxidation process occurs via a biphasic mechanism between $\mathrm{LiVPO}_{4} \mathrm{O}$ and $\mathrm{VPO}_{4} \mathrm{O}$ [14]. The crystal structure of this $\mathrm{V}^{5+}$ phase $\left(\varepsilon-\mathrm{VPO}_{4} \mathrm{O}\right)$ is described in a $C_{c}$ space group allowing the formation of vanadyl bonds appearing as shorter than the ones observed in $\mathrm{LiVPO}_{4} \mathrm{O}$ (i.e., 1.59 vs. $1.67 \AA$, Figure 10 ). Conversely, the antagonist $\mathrm{V}^{5+\ldots} \mathrm{O}$ bond along the chains elongates from $2.2 \AA$ in $\mathrm{LiVPO}_{4} \mathrm{O}$ to $2.5 \AA$ in $\mathrm{VPO}_{4} \mathrm{O}$ leading to an unconventional increase in the cell volume during lithium extraction $(\Delta \mathrm{V} / \mathrm{V}=4.1 \%)$ [63]. This $\mathrm{VPO}_{4} \mathrm{O}$ polymorph can also be obtained while deintercalating the homeotype $\mathrm{LiVPO}_{4} \mathrm{OH}$ (and also $\mathrm{VPO}_{4} \cdot \mathrm{H}_{2} \mathrm{O}$ ), according to an original mechanism $[64,65]$. Indeed, $\mathrm{VPO}_{4} \mathrm{OH}$ appears instable vs. $\mathrm{LiVPO}_{4} \mathrm{OH}$ and $\mathrm{VPO}_{4} \mathrm{O}$ as this $\mathrm{V}^{4+}$-rich phase is not formed upon $\mathrm{Li}^{+}$deintercalation from $\mathrm{LiVPO}_{4} \mathrm{OH}$. On the contrary, $\mathrm{VPO}_{4} \mathrm{O}$ is formed showing that the $\mathrm{V}^{3+}-\mathrm{O} / \mathrm{V}^{5+}=\mathrm{O}$ redox couple is activated at a constant equilibrium voltage of $3.95 \mathrm{~V} \mathrm{vs.} \mathrm{Li}^{+} / \mathrm{Li}$ [65]. Indeed, in the $\mathrm{VPO}_{4} \mathrm{OH}$ hypothetical phase the competition between the two highly covalent bonds, $\mathrm{V}^{4+}=\mathrm{O}$ on one side and $\mathrm{O}-\mathrm{H}$ bond on the other side, would destabilize the $\mathrm{V}^{\mathrm{IV}}-\mathrm{O}-\mathrm{H}$ sequence, leading to the concomitant extraction of $\mathrm{Li}^{+}$and $\mathrm{H}^{+}$and to the atypical two-electron $\mathrm{V}^{3+} / \mathrm{V}^{5+}=\mathrm{O}$ redox reaction at a constant voltage. Unfortunately, on the contrary to the two-electron reaction observed in $\mathrm{Li}_{\mathrm{x}} \mathrm{VPO}_{4} \mathrm{O}$ over $3.2 \mathrm{~V}$, which is reversible but not practical, this one observed at a constant high voltage leads to an irreversible phase transformation. 
The $\mathrm{Li}^{+}$insertion within $\mathrm{LiVPO}_{4} \mathrm{O}$ involves two intermediate phases, $\mathrm{Li}_{1.5} \mathrm{VPO}_{4} \mathrm{O}$ and $\mathrm{Li}_{1.75} \mathrm{VPO}_{4} \mathrm{O}$, before reaching the $\mathrm{Li}_{2} \mathrm{VPO}_{4} \mathrm{O}$ [66]. Although this $\mathrm{V}^{3+}$-rich composition is described in a triclinic $(P-1, Z=4)$ system allowing the formation of a vanadyl-type distortion along the chains, the refined $\mathrm{V}-\mathrm{O}$ distances do not reveal significant differences between them [63], in agreement with the weak Jahn Teller activity of $\mathrm{V}^{3+}\left(\mathrm{d}^{2} \mathrm{t} 2 \mathrm{~g}^{2} \mathrm{eg}\right)$. Lin et al. [67] studied in detail the structural evolutions at the local scale during the lithium insertion in $\mathrm{Li}_{1+\mathrm{x}} \mathrm{VPO}_{4} \mathrm{O}$, and $\mathrm{V} \mathrm{K}$-edge EXAFS shows the disappearance of vanadyl bond for $\mathrm{Li}_{1.5} \mathrm{VPO}_{4} \mathrm{O}$ and the persistence of the longer antagonist until $\mathrm{Li}_{1.75} \mathrm{VPO}_{4} \mathrm{O}$ in good agreement with the phase transitions observed (Figure 11).

The investigation of $\mathrm{LiVPO}_{4} \mathrm{~F}$ started in 2003 with a series of studies conducted by Barker and co-workers $[60,68,69]$ who highlighted the promising performance of this material. Indeed, the high voltage delivered for the Lithium extraction $\left(4.25 \mathrm{~V} \mathrm{vs} . \mathrm{Li}^{+} / \mathrm{Li}\right.$ for the $\mathrm{V}^{3+} / \mathrm{V}^{4+}$ redox voltage, Figure 12) and a capacity very close to the theoretical one even at high C-rate confer to this material a higher practical energy density compared to the ones of commercially available $\mathrm{LiFePO}_{4}$ and $\mathrm{LiCoO}_{2}$ (655 vs. 585 and $525 \mathrm{Wh} / \mathrm{kg}$ respectively).
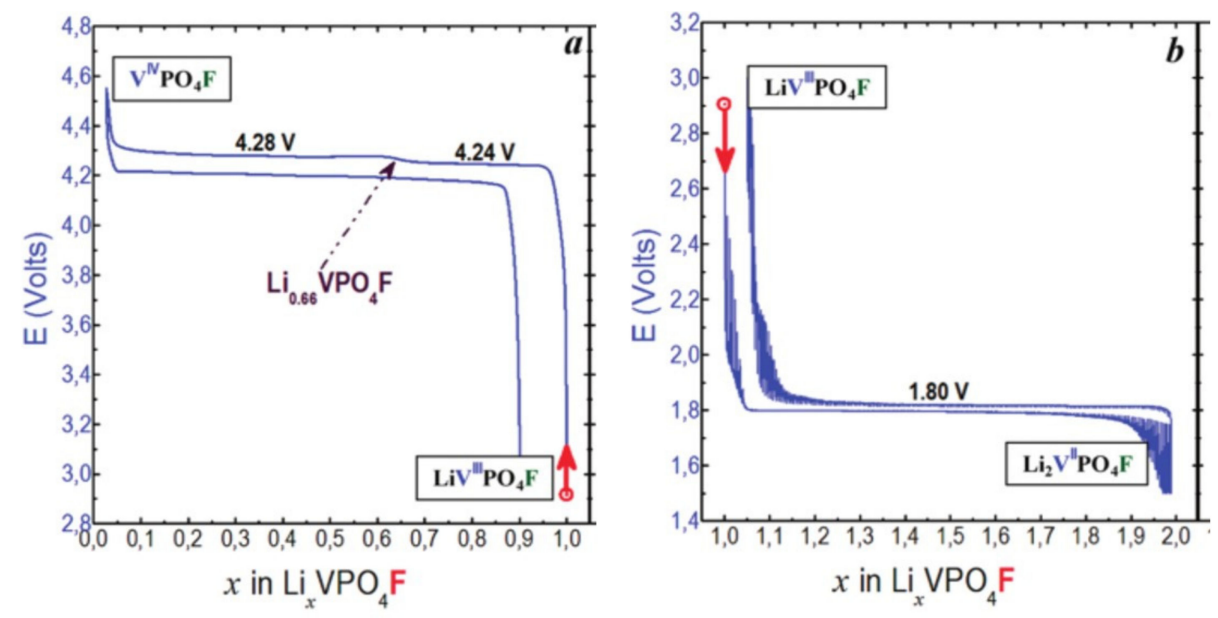

Figure 12. Voltage profile of $\mathrm{Li}_{\mathrm{x}} \mathrm{VPO}_{4} \mathrm{~F}$ cycled between 3.0-4.6 V vs. $\mathrm{Li}^{+} / \mathrm{Li}$ (left) and between 3.0

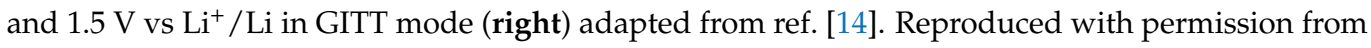
Ateba Mba et al., Chemistry of Materials; published by American Chemical Society, 2012.

The Lithium extraction from $\mathrm{LiVPO}_{4} \mathrm{~F}$ involves an intermediate phase, $\mathrm{Li}_{2 / 3} \mathrm{VPO}_{4} \mathrm{~F}$, and then $\mathrm{VPO}_{4} \mathrm{~F}$ through two biphasic reactions. The crystal structure of $\mathrm{VPO}_{4} \mathrm{~F}$ was reported by Ellis et al. [70], its $C 2 / c$ space group involving centrosymmetric vanadium octahedra with V-F distances of $1.95 \AA$ (Figure 13) whereas the actual nature of the $\mathrm{Li}_{2 / 3} \mathrm{VPO}_{4} \mathrm{~F}$ phase is still unclear, although superstructure peaks have been identified and indexed by doubling the $b$ parameter [71]. This intermediate phase is not formed during discharge where a biphasic reaction between the end-member compositions $\mathrm{VPO}_{4} \mathrm{~F}$ and $\mathrm{LiVPO}_{4} \mathrm{~F}$ takes place [72]. This asymmetric charge/discharge mechanism is not understood at the moment even though it was first attributed by Ellis et al. to the presence of two lithium sites partially occupied $(0.8 / 0.2)$ in the starting $\mathrm{LiVPO}_{4} \mathrm{~F}$. Nevertheless, this hypothesis was ruled out later by Ateba Mba et al. [67] who localized Lithium in a single fully occupied site. Piao et al. [73] conducted operando V-K edge XANES in order to probe the redox mechanism during delithiation of $\mathrm{LiVPO}_{4} \mathrm{~F}$. By a principal component analysis, three components were required to fit the series of spectra recorded upon charge. This might suggest at least a $\mathrm{V}^{3+} / \mathrm{V}^{4+}$ ordering for $\mathrm{Li}_{2 / 3} \mathrm{VPO}_{4} \mathrm{~F}$. The lithium insertion into $\mathrm{LiVPO}_{4} \mathrm{~F}$ occurs at low voltage, typical for the $\mathrm{V}^{3+} / \mathrm{V}^{2+}$ redox couple (i.e., $1.8 \mathrm{~V} \mathrm{vs.} \mathrm{Li}^{+} / \mathrm{Li}$ ) through a biphasic reaction leading to the formation of $\mathrm{Li}_{2} \mathrm{VPO}_{4} \mathrm{~F}$ (Figure 12). The structure of $\mathrm{Li}_{2} \mathrm{VPO}_{4} \mathrm{~F}$ is described in a $\mathrm{C} 2 / \mathrm{c}$ space group with $\mathrm{V}^{2+}$ sitting in a centrosymmetric $\mathrm{VO}_{4} \mathrm{~F}_{2}$ octahedra with V-F distances at 2.10 $\mathrm{A}$ and equatorial V-O ones at $2.13 \AA$ in average [70] 
(Figure 13) while $\mathrm{Li}^{+}$ions are distributed between two $8 \mathrm{f}$ Wyckoff sites half occupied in $\mathrm{LiO}_{3} \mathrm{~F}_{2}$ environments.

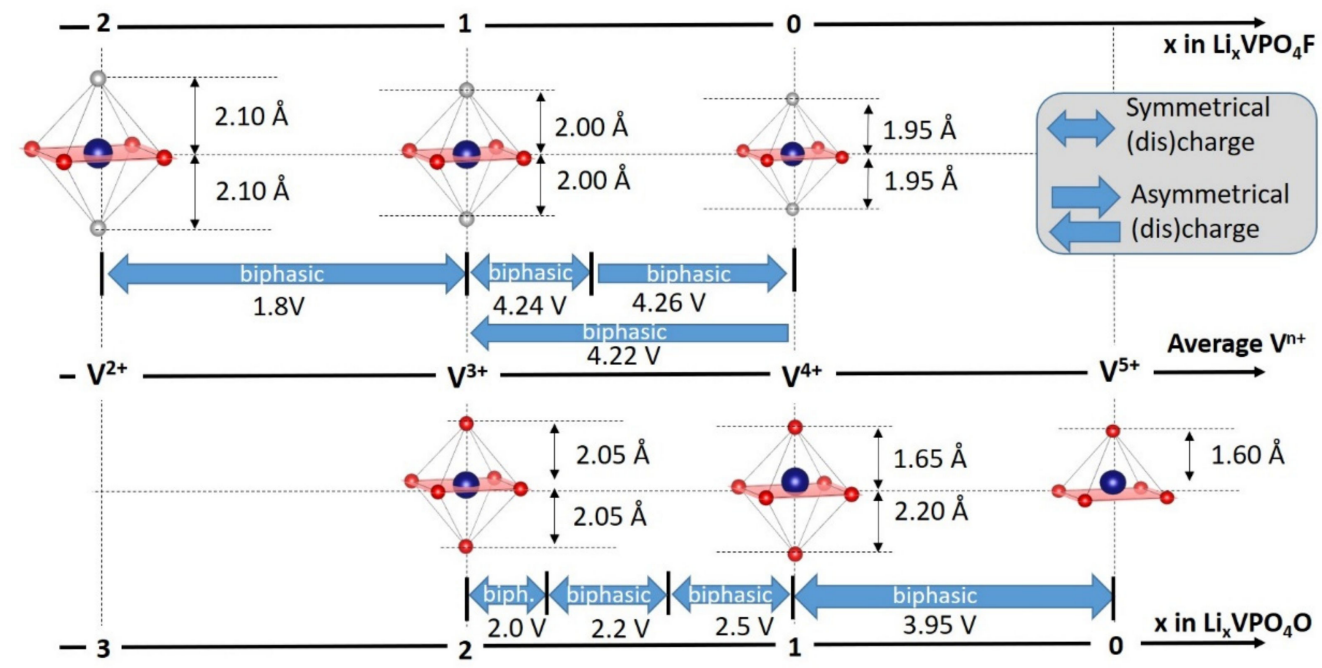

Figure 13. Structural evolution during Lithium extraction/insertion from/into $\mathrm{LiVPO}_{4} \mathrm{~F}[72]$ and $\mathrm{LiVPO}_{4} \mathrm{O}[63,67]$.

Various chemical routes to obtain polycrystalline powders of Tavorite $\mathrm{LiVPO}_{4} \mathrm{~F}$ were reported: sol-gel-assisted carbo thermal reduction (CTR) [74], ionothermal [75]. The majority of these reports highlight the difficulty to obtain pure powders (i.e., without antiNASICON Li $\mathrm{V}_{2}\left(\mathrm{PO}_{4}\right)_{3}$ impurity) or vanadyl-free compounds. Indeed, a series of recent papers demonstrated, by ${ }^{7} \mathrm{Li} \mathrm{NMR}$ (and its $2 \mathrm{D}$ analogue) and DFT calculations, the presence of various amounts of vanadyl-type defects in crystallographically pure " $\mathrm{LiVPO}_{4} \mathrm{~F}^{\prime}[76,77]$. Recently, B. Kang and co-workers [78] reported on an ingenious strategy to avoid the fluorine loss during synthesis, using PTFE as an additional fluorine source. The material thus obtained reveals high electrochemical performance with a stable discharge capacity of $120 \mathrm{mAh} / \mathrm{g}$ at $10 \mathrm{C}$ over 500 cycles. The same group also published for the first time the electrochemical properties of the mixed valence $\mathrm{V}^{3+} / \mathrm{V}^{4+} \mathrm{LiVPO}_{4} \mathrm{~F}_{0.25} \mathrm{O}_{0.75}$ [79]. This strategy aimed at decreasing the difference in voltage between $\mathrm{Li}$ insertion and extraction reactions, conferring to the material a high energy density (i.e., $820 \mathrm{Wh} / \mathrm{kg}$ ) in a reduced voltage range (i.e., $2.0-4.5 \mathrm{~V}$ vs. $\mathrm{Li}^{+} / \mathrm{Li}$ ) with the activation of the $\mathrm{V}^{3+} / \mathrm{V}^{4+}$ and $\mathrm{V}^{4+} / \mathrm{V}^{5+}$ redox couples, respectively. Further investigation of the $\mathrm{LiVPO}_{4} \mathrm{~F}-\mathrm{LiVPO}{ }_{4} \mathrm{O}$ tie-line has allowed several compositions to stabilize in which the competition between ionicity of the $\mathrm{V}^{3+}-\mathrm{F}$ bond and covalency of the $\mathrm{V}^{4+}=\mathrm{O}$ bond distorts the structure, freezes the framework upon Li extraction and hence allows for improved rate capabilities compared with the end-member phases $[80,81]$. Interestingly, upon Li deintercalation from these materials, the $\mathrm{V}^{4+}=\mathrm{O} / \mathrm{V}^{5+}=\mathrm{O}$ redox couple is triggered first before the $\mathrm{V}^{3+} / \mathrm{V}^{4+}$ is activated in fluorine rich environments leading to the formation of a mixed valence $\mathrm{V}^{3+}-\mathrm{V}^{5+}$ phase at half charge [81]. Although surprising, this redox mechanism is in full agreement with the operating voltage of the end-member phases, the $\mathrm{V}^{4+} / \mathrm{V}^{5+}$ redox couple being activated at $3.95 \mathrm{~V}$ in $\mathrm{LiVPO}_{4} \mathrm{O}$ and the $\mathrm{V}^{3+} / \mathrm{V}^{4+}$ redox couple at $4.25 \mathrm{~V}$ in $\mathrm{LiVPO}_{4} \mathrm{~F}$ due to the absence of vanadyl distortion in $\mathrm{LiVPO}_{4} \mathrm{~F}$ and $\mathrm{VPO}_{4} \mathrm{~F}$.

Most of the vanadium phosphates discussed above operate at a rather high $\mathrm{V}^{3+} / \mathrm{V}^{4+}$ redox voltage, suggesting a massive improvement of the energy density delivered while triggering the $\mathrm{V}^{4+} / \mathrm{V}^{5+}$ redox couple. However, materials that operate at such a high $\mathrm{V}^{3+} / \mathrm{V}^{4+}$ voltage are usually unable to reversibly exchange several electrons in a narrow enough voltage range. In the following section we will clarify the crystallographic origin of this trend and identify the strategies able to overcome this issue. 


\section{Towards Reversible High-Voltage Multi-Electron Reactions}

Many other vanadium phosphates (as well as pyrophosphates and phosphites, see Table 1) have been stabilized and studied as positive electrode materials for $\mathrm{Li}(\mathrm{Na})$-ion batteries. This article does not aim at providing an exhaustive review of all of them, however careful descriptions of selected systems, provided above, now allow us to generalize and predict part of their properties (especially working voltages, redox mechanisms and structural evolutions) from the only consideration of their crystal structures in their pristine state.

Table 1. List of the vanadium phosphate, pyro-phosphate and phosphite materials with their redox voltage and corresponding practical capacity based on vanadium redox. More details about the classification of these materials (Type I, II or III) are provided in the text and at the Figure 14.

\begin{tabular}{|c|c|c|c|c|c|c|c|c|c|}
\hline \multirow{2}{*}{$\begin{array}{l}\text { As Synthetized } \\
\text { Compositions }\end{array}$} & \multirow{2}{*}{ Initial $\mathrm{V}^{n+}$} & \multirow{2}{*}{$\begin{array}{l}\text { M/P } \\
\text { Ratio }\end{array}$} & \multicolumn{2}{|c|}{$\mathrm{V}^{2+} / \mathrm{V}^{3+}$} & \multicolumn{2}{|c|}{$\mathrm{V}^{3+} / \mathrm{V}^{4+}$} & \multicolumn{2}{|c|}{$\mathrm{V}^{4+} / \mathrm{V}^{5+}$} & \multirow{2}{*}{ Ref. } \\
\hline & & & $\begin{array}{l}\text { E (V vs. } \\
\left.\mathrm{Li}^{+} / \mathrm{Li}\right)\end{array}$ & $\begin{array}{l}\text { Capacity } \\
(\mathrm{mAh} / \mathrm{g})\end{array}$ & $\begin{array}{l}\text { E (V vs. } \\
\left.\mathrm{Li}^{+} / \mathrm{Li}\right)\end{array}$ & $\begin{array}{l}\text { Capacity } \\
(\mathrm{mAh} / \mathrm{g})\end{array}$ & $\begin{array}{l}\text { E (V vs. } \\
\left.\mathrm{Li}^{+} / \mathrm{Li}\right)\end{array}$ & $\begin{array}{l}\text { Capacity } \\
(\mathrm{mAh} / \mathrm{g})\end{array}$ & \\
\hline \multicolumn{10}{|c|}{ Type I Materials } \\
\hline $\mathrm{Na}_{3} \mathrm{~V}_{2}\left(\mathrm{PO}_{4}\right)_{3}$ & $\mathrm{~V}^{3+}$ & 0.67 & $1.9^{*}$ & 59 & $3.7 *$ & 118 & / & / & [39] \\
\hline $\mathrm{Na}_{3} \mathrm{~V}_{1.5} \mathrm{Al}_{0.5}\left(\mathrm{PO}_{4}\right)_{3}$ & $\mathrm{~V}^{3+}$ & 0.67 & $1.9 *$ & 60 & $3.7^{*}$ & 85 & $4.3 *$ & 28 & [39] \\
\hline $\mathrm{Na}_{3} \mathrm{VCr}\left(\mathrm{PO}_{4}\right)_{3}$ & $\mathrm{~V}^{3+}$ & 0.67 & I & l & $3.7^{*}$ & 60 & $4.4^{*}$ & 50 & [42] \\
\hline $\mathrm{Na}_{4} \mathrm{VMn}\left(\mathrm{PO}_{4}\right)_{3}$ & $\mathrm{~V}^{3+}$ & 0.67 & / & / & $3.7^{*}$ & 60 & $4.2 *$ & 50 & [47] \\
\hline $\mathrm{r}-\mathrm{Li}_{3} \mathrm{~V}_{2}\left(\mathrm{PO}_{4}\right)_{3}$ & $\mathrm{~V}^{3+}$ & 0.67 & I & I & 3.7 & 131 & I & I & [34] \\
\hline $\mathrm{m}-\mathrm{Li}_{3} \mathrm{~V}_{2}\left(\mathrm{PO}_{4}\right)_{3}$ & $\mathrm{~V}^{3+}$ & 0.67 & 1.8 & 131 & 3.9 & 131 & 4.5 & 33 & [27] \\
\hline $\mathrm{LiVP}_{2} \mathrm{O}_{7}$ & $\mathrm{~V}^{3+}$ & 0.5 & 2 & 116 & 4.3 & 95 & / & / & {$[82,83]$} \\
\hline $\mathrm{Na}_{7} \mathrm{~V}_{4}\left(\mathrm{P}_{2} \mathrm{O}_{7}\right)_{3}\left(\mathrm{PO}_{4}\right)_{2}$ & $\mathrm{~V}^{3+}$ & 0.5 & I & I & $4.2 *$ & 90 & I & I & [84] \\
\hline $\mathrm{Na}_{7} \mathrm{~V}_{3} \mathrm{Al}_{1}\left(\mathrm{P}_{2} \mathrm{O}_{7}\right)_{3}\left(\mathrm{PO}_{4}\right)_{2}$ & $\mathrm{~V}^{3+}$ & 0.5 & 1 & I & $4.2 *$ & 77 & 4.5 & 46 & [85] \\
\hline $\mathrm{Na}_{3} \mathrm{~V}\left(\mathrm{PO}_{4}\right)_{2}$ & $\mathrm{~V}^{3+}$ & 0.5 & l & I & $3.8^{*}$ & 90 & $4.4^{*}$ & 20 & {$[86,87]$} \\
\hline $\mathrm{LiV}\left(\mathrm{HPO}_{3}\right)_{2}$ & $\mathrm{~V}^{3+}$ & 0.5 & / & / & 4.1 & 75 & I & I & [88] \\
\hline $\mathrm{Li}_{9} \mathrm{~V}_{3}\left(\mathrm{P}_{2} \mathrm{O}_{7}\right)_{3}\left(\mathrm{PO}_{4}\right)_{2}$ & $\mathrm{~V}^{3+}$ & 0.375 & 1 & 1 & 3.7 & 55 & 4.5 & 55 & [89] \\
\hline $\mathrm{Na}_{7} \mathrm{~V}_{3}\left(\mathrm{P}_{2} \mathrm{O}_{7}\right)_{4}$ & $\mathrm{~V}^{3+}$ & 0.375 & I & I & $4.3^{*}$ & 80 & I & I & [90] \\
\hline $\mathrm{Na}_{3} \mathrm{~V}\left(\mathrm{PO}_{3}\right)_{3} \mathrm{~N}$ & $\mathrm{~V}^{3+}$ & 0.33 & I & I & $4.3^{*}$ & 74 & I & I & [91] \\
\hline \multicolumn{10}{|c|}{ Type II Materials } \\
\hline $\mathrm{LiVPO}_{4} \mathrm{~F}$ & $\mathrm{~V}^{3+}$ & 1 & 1.8 & 156 & 4.2 & 156 & I & I & [14] \\
\hline $\mathrm{NaVPO}_{4} \mathrm{~F}$ & $\mathrm{~V}^{3+}$ & 1 & / & / & $\approx 4.2 *$ & 20 & / & / & [92] \\
\hline $\mathrm{LiVPO}_{4} \mathrm{OH}$ & $\mathrm{V}^{3+}$ & 1 & 1.4 & 155 & I & I & I & I & [65] \\
\hline$(\mathrm{Li}, \mathrm{K}) \mathrm{VPO}_{4} \mathrm{~F}$ & $\mathrm{~V}^{3+}$ & 1 & 1 & 1 & 4.0 & 110 & 1 & 1 & [93] \\
\hline $\mathrm{Na}_{3} \mathrm{~V}_{2}\left(\mathrm{PO}_{4}\right)_{2} \mathrm{~F}_{3}$ & $\mathrm{~V}^{3+}$ & 0.67 & $1.5^{*}$ & 64 & $4.0^{*}$ & 64 & $\approx 4.8^{*}$ & 64 & {$[51,53,94]$} \\
\hline $\mathrm{Li}_{5} \mathrm{~V}\left(\mathrm{PO}_{4}\right)_{2} \mathrm{~F}_{2}$ & $\mathrm{~V}^{3+}$ & 0.5 & I & I & 4.15 & 85 & 4.7 & 85 & [95] \\
\hline $\mathrm{t}-\mathrm{Na}_{5} \mathrm{~V}\left(\mathrm{PO}_{4}\right)_{2} \mathrm{~F}_{2}$ & $\mathrm{~V}^{3+}$ & 0.5 & 1 & 1 & $3.7 *$ & 62 & I & 1 & [96] \\
\hline $\mathrm{o}-\mathrm{Na}_{5} \mathrm{~V}\left(\mathrm{PO}_{4}\right)_{2} \mathrm{~F}_{2}$ & $\mathrm{~V}^{3+}$ & 0.5 & 1 & I & $3.9^{*}$ & 65 & I & I & [96] \\
\hline \multicolumn{10}{|c|}{ Type III Materials } \\
\hline$\alpha-\mathrm{LiVPO}_{4} \mathrm{O}$ & $\mathrm{V}^{4+}$ & 1 & I & I & 2.4 & 155 & 3.95 & 150 & [14] \\
\hline$\beta-\mathrm{LiVPO}_{4} \mathrm{O}$ & $\mathrm{V}^{4+}$ & 1 & 1 & I & 2.2 & 155 & 4 & 130 & [97] \\
\hline$\beta-\mathrm{NaVPO}_{4} \mathrm{O}$ & $\mathrm{V}^{4+}$ & 1 & / & / & / & / & $3.6^{*}$ & 58 & [98] \\
\hline$\gamma-\mathrm{LiVPO}_{4} \mathrm{O}$ & $\mathrm{V}^{4+}$ & 1 & I & 1 & 2 & 80 & 4 & 150 & [99] \\
\hline $\mathrm{Li}_{4} \mathrm{VO}\left(\mathrm{PO}_{4}\right)_{2}$ & $\mathrm{~V}^{4+}$ & 0.5 & 1 & 1 & 2 & 94 & 4.1 & 94 & [100] \\
\hline $\mathrm{Na}_{4} \mathrm{VO}\left(\mathrm{PO}_{4}\right)_{2}$ & $\mathrm{~V}^{4+}$ & 0.5 & I & I & I & I & $3.8^{*}$ & 77 & [101] \\
\hline $\mathrm{Li}_{2} \mathrm{VOP}_{2} \mathrm{O}_{7}$ & $\mathrm{~V}^{4+}$ & 0.5 & / & / & / & / & 4.1 & 64 & [102] \\
\hline
\end{tabular}

The voltage values are reported vs. $\mathrm{Li}^{+} / \mathrm{Li}$ even for those obtained in $\mathrm{Na}$-cell (according to $\mathrm{E}\left(\mathrm{Na}^{+} / \mathrm{Na}\right)=0.3 \mathrm{Vvs}$. $\left.\mathrm{Li}^{+} / \mathrm{Li}\right)$, in that case the voltage is marked by * 


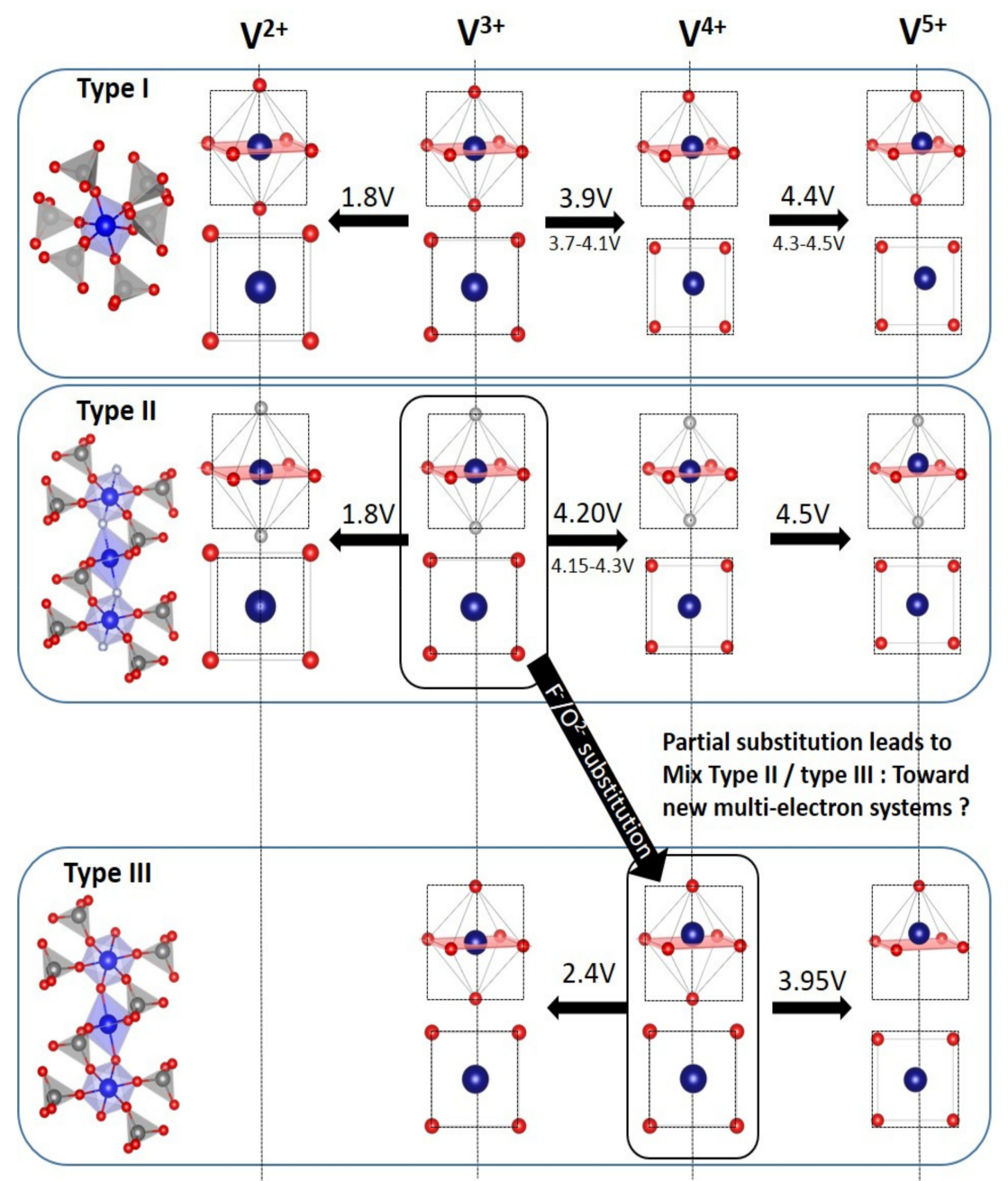

Figure 14. Typical evolution of vanadium environments according to the oxidation state of vanadium for type I, type II and type III materials.

Table 1 highlights the significant divergence in the $\mathrm{V}^{3+} / \mathrm{V}^{4+}$ redox voltages which cannot be attributed to the inductive effect, the cation-cation repulsions or even Li site energy, which are the main reported features impacting the voltage in polyanions $[103,104]$. Indeed, the voltage for the $\mathrm{V}^{3+} / \mathrm{V}^{4+}$ redox couple in the Tavorite system $\mathrm{Li}_{\mathrm{x}} \mathrm{VPO}_{4} \mathrm{Y}$ (with $\mathrm{Y}=\mathrm{O}$ or $\mathrm{F})$ varies from $2.4 \mathrm{~V}$ for $\mathrm{Li}_{1+\mathrm{x}} \mathrm{VPO}_{4} \mathrm{O}(0 \leq \mathrm{x} \leq 1)$ to $4.26 \mathrm{~V}$ in $\mathrm{Li}_{1-\mathrm{x}} \mathrm{VPO}_{4} \mathrm{~F}(0 \leq \mathrm{x} \leq 1)$. This is attributed to the effect of the highly covalent vanadyl bond which is observed for oxidation states of vanadium strictly superior to 3 in $\mathrm{Li}_{1-\mathrm{x}} \mathrm{VPO}_{4} \mathrm{O}, \mathrm{Na}_{4} \mathrm{VO}\left(\mathrm{PO}_{4}\right)_{2} \ldots$ These structures present a common crystallographic feature: at least one oxygen around vanadium is not involved in a covalent $\mathrm{P}-\mathrm{O}$ bond and hence could be engaged in a vanadyl bond. In the compounds where the $\mathrm{VO}_{6}$ octahedra share all their oxygen atoms with $\mathrm{PO}_{4}$ (or $\mathrm{P}_{2} \mathrm{O}_{7}$ ) groups, the structure of the de-alkalinated $\mathrm{V}^{4+}$ phases are vanadyl free with $\mathrm{VO}_{6}$ octahedra slightly distorted. The corresponding vanadyl free $\mathrm{V}^{3+} / \mathrm{V}^{4+}$ redox couple is located at $3.9 \mathrm{~V}$ in monoclinic $\mathrm{Li}_{3-\mathrm{x}} \mathrm{V}_{2}\left(\mathrm{PO}_{4}\right)_{3}$ and $4.2 \mathrm{~V}$ in $\mathrm{Li}_{1-\mathrm{x}} \mathrm{VP}_{2} \mathrm{O}_{7}$, a much higher voltage than the $\mathrm{V}^{3+} / \mathrm{V}^{4+}$ couple involved in $\mathrm{Li}_{1+\mathrm{x}} \mathrm{VPO}_{4} \mathrm{O}$ polymorphs (around $2.3 \mathrm{~V}$ vs. $\left.\mathrm{Li}^{+} / \mathrm{Li}\right)$.

Boudin et al. [15] proposed a classification of the vanadium phosphates into three groups according to size of the "clusters" of vanadium polyhedra $\left(\left[\mathrm{VO}_{\mathrm{x}}\right]_{n}\right.$ with $\left.1<n<\infty\right)$. Although this classification is pertinent to the discussion of the catalytic or magnetic properties of vanadium phosphates, it does not really make sense for a discussion of electrochemical properties. Therefore, we chose to sort these materials considering vanadyl- 
forbidden (type I and type II) and vanadyl-allowed (type III) structures (summarized in Table 1 and Figure 14):

- $\quad$ For type I materials (e.g., $\left.\mathrm{Li}_{3} \mathrm{~V}_{2}\left(\mathrm{PO}_{4}\right)_{3}\right)$, in which the vanadyl bond cannot appear due to the involvement of each oxygen atom of $\mathrm{VO}_{6}$ octahedra in a $\mathrm{PO}_{4}$-type entity, the typical evolution of the vanadium environment upon oxidation (from $\mathrm{V}^{2+}$ to $\mathrm{V}^{5+}$ ) follows a quasi-homogeneous shortening of $\mathrm{V}-\mathrm{O}$ bonds from $\mathrm{V}^{2+}$ to $\mathrm{V}^{4+}$ and a strong increase in $\mathrm{VO}_{6}$ distortion to reach the $\mathrm{V}^{5+}$ state with corresponding voltages of $1.8 \mathrm{~V}$ vs. $\mathrm{Li}^{+} / \mathrm{Li}$ for $\mathrm{V}^{2+} / \mathrm{V}^{3+}, 3.9 \mathrm{~V}$ vs. $\mathrm{Li}^{+} / \mathrm{Li}$ for $\mathrm{V}^{3+} / \mathrm{V}^{4+}$ and $4.4 \mathrm{~V}$ vs. $\mathrm{Li}^{+} / \mathrm{Li}_{\text {for }} \mathrm{V}^{4+} / \mathrm{V}^{5+}$ redox couples (on average for all the type I materials reported in Table 1).

- In type II materials (e.g., $\mathrm{LiVPO}_{4} \mathrm{~F}$ ), at least one of the ligands around vanadium is unshared with a phosphate group and hence would be available to form the vanadyl bond. However, in that case, the nature of this ligand $\left(\mathrm{F}^{-}\right.$instead of $\left.\mathrm{O}^{2-}\right)$ inhibits its formation. From $\mathrm{V}^{2+}$ to $\mathrm{V}^{4+}$, the evolution of the vanadium environment follows a similar trend with slightly higher voltages than for type I due to the higher ionicity of V-F versus V-O. For $\mathrm{V}^{5+}$, for instance in deintercalated $\mathrm{Na}_{3} \mathrm{~V}_{2}\left(\mathrm{PO}_{4}\right)_{2} \mathrm{~F}_{3}$, a "vanadyllike" distortion appears with V-F bond length of $1.6 \AA$ and $1.9 \AA$. Such an F $\cdots$ V-F sequence has never been reported elsewhere and the precise nature of the V-F bonds formed is still to be clarified.

- $\quad$ Type III group (e.g., $\mathrm{LiVPO}_{4} \mathrm{O}$ ) gathers the structures having at least one oxygen belonging to $\mathrm{VO}_{6}$ octahedra available to form the covalent vanadyl bond for vanadium oxidation states higher than 3 . In this class of materials, the $\mathrm{V}^{3+}$ environments are quasi undistorted. As the oxidation state of vanadium is increased, vanadium leaves the inversion center of the $\mathrm{VO}_{6}$ octahedra in order to form the vanadyl bond. The formation of a distorted $\mathrm{V}^{\mathrm{IV}} \mathrm{O}_{6}$ octahedra (with typical distances ranging between 1.6 and $2.4 \AA$ along $\mathrm{dz}^{2}$ and quasi equivalent equatorial distances around $2 \AA$ ) and $\mathrm{V}^{\mathrm{V}} \mathrm{O}_{5}$ pyramids (in which the short $\mathrm{V}=\mathrm{O}$ bond is about $1.6 \AA$ and a shortening of the equatorial distances is observed around 1.8-1.9 $\AA$ ) are observed. The corresponding voltages appear completely different to those of type I and type II materials: $2.4 \mathrm{~V} \mathrm{vs.} \mathrm{Li}^{+} / \mathrm{Li}$ for the $\mathrm{V}^{3+}-\mathrm{O} / \mathrm{V}^{4+}=\mathrm{O}$ and $3.95 \mathrm{~V}$ vs. $\mathrm{Li}^{+} / \mathrm{Li}$ for the $\mathrm{V}^{4+}=\mathrm{O} / \mathrm{V}^{5+}=\mathrm{O}$ redox couples.

Note that type II materials are crystallographically pseudo type III ones in which the oxygen involved in the vanadyl bond is replaced by Fluorine. Therefore, partial substitution of this fluorine by oxygen leads to mixed type II/III materials-which is actually the case for most of the type III materials, difficult to obtain as vanadyl-free. Extended oxyfluorine solid solutions were investigated for $\mathrm{Na}_{3} \mathrm{~V}_{2}\left(\mathrm{PO}_{4}\right)_{2} \mathrm{~F}_{3-y} \mathrm{O}_{\mathrm{y}}[54,55,57,58]$ and for $\mathrm{LiVPO}_{4} \mathrm{~F}_{1-\mathrm{y}} \mathrm{O}_{\mathrm{y}}[79-81,105,106]$. The particularity of these compounds resides in the redox paradox of vanadium where the $\mathrm{V}^{4+}=\mathrm{O} / \mathrm{V}^{5+}=\mathrm{O}$ is activated at lower voltage than the $\mathrm{V}^{3+}-\mathrm{F} / \mathrm{V}^{4+}-\mathrm{F}[55,81,107]$. Depending on the distribution of ligands around $\mathrm{V}$, it behaves as type II $\left(\mathrm{V}^{3+} \mathrm{O}_{4} \mathrm{~F}_{2}\right)$, type III $\left(\mathrm{V}^{4+} \mathrm{O}_{4} \mathrm{O}_{2}\right)$ or mixed type II/III $\left(\mathrm{V}^{3 / 4+} \mathrm{O}_{4} \mathrm{OF}\right)[81]$. For this latter environment, the $\mathrm{V}^{5+}=\mathrm{O}$ vanadyl-like distortion is allowed upon cycling, promoting the reversibility of the process, but is observed at higher voltage than type III materials thanks to the antagonist fluorine. This highlights the importance of the heteroleptic units formed in statistically distributed or in peculiar $\mathrm{O} / \mathrm{F}$ ordered compounds which are somewhat difficult to obtain due to the different nature of the $\mathrm{V}^{4+}=\mathrm{O}$ and $\mathrm{V}^{3+}-\mathrm{F}$ bonds promoting their clusterization [108].

This classification makes further sense regarding the ability of each type of vanadium phosphates to reversibly exchange several electrons per transition metal at high voltage and in a narrow enough voltage range. In type III materials multi-electron redox through $\mathrm{V}^{3+}-\mathrm{O} / \mathrm{V}^{4+}=\mathrm{O}$ and $\mathrm{V}^{4+}=\mathrm{O} / \mathrm{V}^{5+}=\mathrm{O}$ couples have often been reported [9-12]. The oxygen atoms unshared with $\mathrm{PO}_{4}$ facilitate the formation of the vanadyl bond allowing for two rather reversible electron processes and thus allow the achievement of cycling stability with energy density higher than $900 \mathrm{Wh} / \mathrm{kg}$ [9]. However, this multi-electron reaction cannot be used in a real battery system due to the large voltage difference between the $\mathrm{V}^{3+}-\mathrm{O} / \mathrm{V}^{4+}=\mathrm{O}$ and $\mathrm{V}^{4+}=\mathrm{O} / \mathrm{V}^{5+}=\mathrm{O}($ ca. $2.5 \mathrm{~V})$ redox couples. Substituting oxygen by fluorine in such a way to obtain $\mathrm{LiVPO}_{4} \mathrm{~F}_{0.75} \mathrm{O}_{0.25}$ allows raising the voltage of the $\mathrm{V}^{3+} / \mathrm{V}^{4+}$ redox and 
hence reversibly intercalating 1.6 electrons per vanadium in a reduced voltage range [79]. However, this material suffers from rapid capacity fading under such conditions. Since then, the possibility to stabilize multiple compositions along the $\mathrm{LiVPO}_{4} \mathrm{~F}-\mathrm{LiVPO}_{4} \mathrm{O}$ tie-line has been demonstrated and a systemic investigation of substitution ratio (i.e., y) vs. the voltage range could allow fixing this issue by controlling the $\Delta \mathrm{x}$ in $\mathrm{Li}_{1 \pm \mathrm{x}} \mathrm{VPO}_{4} \mathrm{~F}_{1-\mathrm{y}} \mathrm{O}_{\mathrm{y}}$.

In type I and type II materials, while the low voltage $\mathrm{V}^{2+} / \mathrm{V}^{3+}\left(\approx 1.8 \mathrm{~V} \mathrm{vs.} \mathrm{Li}^{+} / \mathrm{Li}\right)$ and high voltage $\mathrm{V}^{3+} / \mathrm{V}^{4+}\left(3.9-4.2 \mathrm{~V} v\right.$ s. $\left.\mathrm{Li}^{+} / \mathrm{Li}\right)$ redox are easily triggered, the $\mathrm{V}^{4+} / \mathrm{V}^{5+}$ redox is rarely reported (see Table 1). Moreover, this latter is often kinetically limited and/or irreversible, most probably due to the structural rearrangements required to provide to $\mathrm{V}^{5+}$ cations a satisfying environment. Indeed, the $\mathrm{V}^{5+}$ cations are stable either in a pyramidal $([1+4]$ coordination $)$ or in a tetrahedral $([2+2]$ coordination) or even in a very distorted octahedral $([2+2+2]$ coordination) [15] environments. In each case, at least one covalent vanadyl bond must be formed, but this formation is not privileged by the crystallographic arrangements adopted by type I and II materials. In order to provide to the $\mathrm{V}^{5+}$ cations with a more stable environment than this distorted octahedral one, migration of $\mathrm{V}^{5+}$ in tetrahedral site has been proposed [32]. Therefore, kinetic limitations and/or an irreversible capacity, which can be compensated only at very low voltage (as seen in $\mathrm{Na}_{3} \mathrm{~V}_{2}\left(\mathrm{PO}_{4}\right)_{2} \mathrm{~F}_{3}$, $\mathrm{Li}_{3} \mathrm{~V}_{2}\left(\mathrm{PO}_{4}\right)_{3}, \mathrm{Li}_{5} \mathrm{~V}\left(\mathrm{PO}_{4}\right)_{2} \mathrm{~F}_{2}$ and $\left.\mathrm{Li}_{9} \mathrm{~V}_{3}\left(\mathrm{P}_{2} \mathrm{O}_{7}\right)_{3}\left(\mathrm{PO}_{4}\right)_{2}\right)$, appear. Although $\mathrm{V}^{5+}$ migration in tetrahedral sites has been reported only in $\mathrm{Li}_{3} \mathrm{~V}_{2}\left(\mathrm{PO}_{4}\right)_{3}$ so far, analyzing the electrochemical response upon subsequent discharge for other compounds gives insight about the nature of the irreversible reaction taking place. For instance, in $\mathrm{Na}_{3} \mathrm{~V}_{2}\left(\mathrm{PO}_{4}\right)_{2} \mathrm{~F}_{3}$, the Na re-insertion into $\mathrm{V}_{2}\left(\mathrm{PO}_{4}\right) \mathrm{F}_{3}$ (i.e., $\left.\mathrm{V}^{4.5+}\right)$ occurs at $3.9 \mathrm{~V}$ vs. $\mathrm{Na}^{+} / \mathrm{Na}$ in average, until the composition $\mathrm{Na}_{2} \mathrm{~V}_{2}\left(\mathrm{PO}_{4}\right)_{2} \mathrm{~F}_{3}\left(\mathrm{~V}^{4.5+}\right.$ to $\left.\mathrm{V}^{3.5+}\right)$ : this voltage range is associated to the $\mathrm{Na}_{3}\left(\mathrm{~V}^{3+}\right)-\mathrm{Na}_{1}\left(\mathrm{~V}^{4+}\right)$ composition range during the previous charge. The further $\mathrm{Na}$ insertion occurs at $1.6 \mathrm{~V}$ vs. $\mathrm{Na}^{+} / \mathrm{Na}$ until the composition $\mathrm{Na}_{3} \mathrm{~V}_{2}\left(\mathrm{PO}_{4}\right)_{2} \mathrm{~F}_{3}$ is recovered. Moreover, the length of this low voltage plateau is proportional to the amount of vanadium oxidized above $\mathrm{V}^{4+}$ during the previous charge. Therefore, this low voltage feature is more likely to correspond to the reduction in $\mathrm{V}^{3+}$ (i.e., $\approx 1.5 \mathrm{~V}$ vs. $\mathrm{Na}^{+} / \mathrm{Na}$ for $\mathrm{V}^{3+} / \mathrm{V}^{2+}$ redox in type $\mathrm{I}$ and type II materials) rather than to the reduction in the $\mathrm{V}^{4+}$ into $\mathrm{V}^{3+}$ (i.e., 3.6-3.9 $\mathrm{V}$ vs. $\mathrm{Na}^{+} / \mathrm{Na}$ ). This behavior could agree with the presence of $\mathrm{V}^{5+}$ in $\mathrm{Td}$ sites. Indeed, as seen in transition metal vanadates used as anode in alkali-ion batteries [109], $\mathrm{V}^{5+} \mathrm{Td}$ is not reduced above $1.5 \mathrm{~V}$ vs. $\mathrm{Li}^{+} / \mathrm{Li}$ without migrating back in an octahedral site. Therefore, the $\mathrm{V}^{3+}$ reduction would occur at a higher voltage than the $\mathrm{V}^{5+} \mathrm{Td}$ reduction. The presence of oxygen in the fluorine site would help in accommodating $\mathrm{V}^{5+}$ cation in distorted octahedral site in the charged state. Indeed, it has been shown by theoretical calculations that the partial substitution of fluorine by oxygen in such a way to obtain $\mathrm{Na}_{3} \mathrm{~V}_{2}\left(\mathrm{PO}_{4}\right)_{2} \mathrm{~F}_{3-\mathrm{x}} \mathrm{O}_{\mathrm{x}}$ composition tends to decrease the voltage of extraction of the third $\mathrm{Na}^{+}$cations (from $4.9 \mathrm{~V}$ to $4.7 \mathrm{~V}$ vs. $\mathrm{Na}^{+} / \mathrm{Na}$ from pure fluoride to oxy-fluoride) leading to the reversible exchange of more than one electron per vanadium with an excellent rate capability [55].

Finally, this review reveals that the versatility of the vanadium chemistry with a large number of stable oxidation states stabilized in very different environments opens the road towards the formation of new materials whose strains imposed by the crystal field give attractive electrochemical properties. While, in the battery field, the search for new polyanion positive electrode materials slows down for few years, maintaining the efforts towards the stabilization of new phases is crucial. LiVPO $\mathrm{F}_{1-\mathrm{x}} \mathrm{O}_{\mathrm{x}}$ and $\mathrm{Na}_{3} \mathrm{~V}_{2}\left(\mathrm{PO}_{4}\right)_{2} \mathrm{~F}_{3-\mathrm{x}} \mathrm{O}_{\mathrm{x}}$ are the only vanadium phosphate oxy-fluorides studied as positive electrode materials and have shown very promising properties. Further playing with anionic substitution, not only with vanadium phosphate oxy-fluorides but also oxy-nitrides (as recently reported with $\mathrm{Na}_{3} \mathrm{~V}_{2}\left(\mathrm{PO}_{3}\right)_{3} \mathrm{~N}$ [91]) and even oxy-sulfides, would offer new degrees of flexibility for such versatile polyanion systems and could allow the achievement of high energy density (ca. $1 \mathrm{kWh} / \mathrm{kg}$ of active positive electrode material corresponding to ca. $400 \mathrm{Wh} / \mathrm{kg}$ at the cell level) through reversible high-voltage multi-electron redox. 


\section{Conclusions}

This review has identified the vanadyl distortion as the main feature governing the operating voltage in vanadium phosphates and their ability to reversibly store several electrons per transition metal. The classification of such materials in three groups, according to the nature of the ligands in the vanadium octahedra and to the distribution of $\mathrm{PO}_{4}$ around them, has allowed to unveil the strategies to increase their energy density. Indeed, anionic substitutions have led to vanadium phosphate oxy-fluorides which allow to combine the beneficial effect of the vanadyl distortion on the reversibility with the high voltage of vanadium redox couples in fluorine rich environments. Further investigation of these anionic substitutions could allow to tend towards reversible high-voltage multi-electron reactions in Alkali-ion batteries.

Funding: The authors acknowledge FEDER, the Reégion Hauts-de-France and the RS2E Network for the funding of EB's PhD thesis, as well as the financial support of Région Nouvelle Aquitaine, of the French National Research Agency (STORE-EX Labex Project ANR-10-LABX-76-01) and of the European Union's Horizon 2020 research and innovation program under grant agreement No 875629 (NAIMA project).

Institutional Review Board Statement: Not applicable.

Informed Consent Statement: Not applicable.

Data Availability Statement: Not applicable.

Conflicts of Interest: The authors declare no conflict of interest.

\section{References}

1. Padhi, A.K.; Nanjundaswamy, K.S.; Goodenough, J.B. Phospho-Olivines as Positive-Electrode Materials for Rechargeable Lithium Batteries. J. Electrochem. Soc. 1997, 144, 1188-1194. [CrossRef]

2. Andersson, A.S.; Thomas, J.O.; Kalska, B.; Häggström, L. Thermal Stability of LiFePO4-Based Cathodes. Electrochem. Solid State Lett. 2000, 3, 66-68. [CrossRef]

3. Andersson, A.S.; Kalska, B.; Haggstrom, L.; Thomas, J.O. Lithium Extraction/Insertion in LiFePO4: An X-Ray Diffraction and Mössbauer Spectroscopy Study. Solid State Ion. 2000, 130, 41-52. [CrossRef]

4. Yamada, A.; Chung, S.C.; Hinokuma, K. Optimized LiFePO4 for Lithium Battery Cathodes. J. Electrochem. Soc. 2001, 148, 224-229. [CrossRef]

5. Huang, H.; Yin, S.; Nazar, L.F. Approaching Theoretical Capacity of LiFePO4 at Room Temperature at High Rates. Electrochem. Solid State Lett. 2001, 4, 170-172. [CrossRef]

6. Recham, N.; Chotard, J.-N.; Jumas, J.-C.; Laffont, L.; Armand, M.; Tarascon, J.-M. Ionothermal Synthesis of Li-Based Fluorophosphates Electrodes. Chem. Mater. 2010, 22, 1142-1148. [CrossRef]

7. Barpanda, P.; Ati, M.; Melot, B.C.; Rousse, G.; Chotard, J.-N.; Doublet, M.-L.; Sougrati, M.T.; Corr, S.A.; Jumas, J.-C.; Tarascon, J.-M. A 3.90 V Iron-Based Fluorosulphate Material for Lithium-Ion Batteries Crystallizing in the Triplite Structure. Nat. Mater. 2011, 10, 772-779. [CrossRef]

8. Lv, D.; Bai, J.; Zhang, P.; Wu, S.; Li, Y.; Wen, W.; Jiang, Z.; Mi, J.; Zhu, Z.; Yang, Y. Understanding the High Capacity of Li 2 FeSiO 4: In Situ XRD/XANES Study Combined with First-Principles Calculations. Chem. Mater. 2013, 25, 2014-2020. [CrossRef]

9. Siu, C.; Seymour, I.D.; Britto, S.; Zhang, H.; Rana, J.; Feng, J.; Omenya, F.O.; Zhou, H.; Chernova, N.A.; Zhou, G.; et al. Enabling Multi-Electron Reaction of $\varepsilon$-VOPO4 to Reach Theoretical Capacity for Lithium-Ion Batteries. Chem. Commun. 2018, No. 54, 7802-7805. [CrossRef]

10. Shi, Y.; Zhou, H.; Seymour, I.D.; Britto, S.; Rana, J.; Wangoh, L.W.; Huang, Y.; Yin, Q.; Reeves, P.J.; Zuba, M.; et al. Electrochemical Performance of Nanosized Disordered LiVOPO4. ACS Omega 2018, 3, 7310-7323. [CrossRef] [PubMed]

11. Shi, Y.; Zhou, H.; Britto, S.; Seymour, I.D.; Wiaderek, K.M.; Omenya, F.; Chernova, N.A.; Chapman, K.W.; Grey, C.P.; Whittingham, M.S. A High-Performance Solid-State Synthesized LiVOPO4 for Lithium-Ion Batteries. Electrochem. Commun. 2019, 105, 106491. [CrossRef]

12. Chung, Y.; Cassidy, E.; Lee, K.; Siu, C.; Huang, Y.; Omenya, F.; Rana, J.; Wiaderek, K.M.; Chernova, N.A.; Chapman, K.W.; et al. Nonstoichiometry and Defects in Hydrothermally Synthesized $\epsilon$-LiVOPO4. ACS Appl. Energy Mater. 2019, 2, 4792-4800. [CrossRef]

13. Rana, J.; Shi, Y.; Zuba, M.J.; Wiaderek, K.M.; Feng, J.; Zhou, H.; Ding, J.; Tianpin, W.; Cibin, G.; Balasubramanian, M.; et al. Role of Disorder in Limiting the True Multi-Electron Redox in $\varepsilon$-LiVOPO4. J. Mater. Chem. A 2018, 42, 1-10. [CrossRef]

14. Ateba Mba, J.; Masquelier, C.; Suard, E.; Croguennec, L. Synthesis and Crystallographic Study of Homeotypic LiVPO4F and LiVPO4O. Chem. Mater. 2012, 24, 1223-1234. [CrossRef] 
15. Boudin, S.; Guesdon, A.; Leclaire, A.; Borel, M.M. Review on Vanadium Phosphates with Mono and Divalent Metallic Cations: Syntheses, Structural Relationships and Classification, Properties. Int. J. Inorg. Mater. 2000, 2, 561-579. [CrossRef]

16. Whittingham, M.S. Ultimate Limits to Intercalation Reactions for Lithium Batteries. Chem. Rev. 2014, 114, 11414-11443. [CrossRef] [PubMed]

17. Croguennec, L.; Palacin, M.R. Recent Achievements on Inorganic Electrode Materials for Lithium-Ion Batteries. J. Am. Chem. Soc. 2015, 137, 3140-3156. [CrossRef]

18. Masquelier, C.; Croguennec, L. Polyanionic (Phosphates, Silicates, Sulfates) Frameworks as Electrode Materials for Rechargeable Li (or Na) Batteries. Chem. Rev. 2013, 113, 6552-6591. [CrossRef] [PubMed]

19. Yabuuchi, N.; Kubota, K.; Dahbi, M.; Komaba, S. Research Development on Sodium-Ion Batteries. Chem. Rev. 2014, 114, 11636-11682. [CrossRef] [PubMed]

20. Shi, H.-Y.; Jia, Z.; Wu, W.; Zhang, X.; Liu, X.-X.; Sun, X. The Development of Vanadyl Phosphate Cathode Materials for Energy Storage Systems: A Review. Chem. A Eur. J. 2020, 26, 8190-8204. [CrossRef] [PubMed]

21. Beneš, L.; Melánová, K.; Svoboda, J.; Zima, V. Intercalation Chemistry of Layered Vanadyl Phosphate: A Review. J. Incl. Phenom. Macrocycl. Chem. 2012, 73, 33-53. [CrossRef]

22. Jian, Z.; Hu, Y.-S.; Ji, X.; Chen, W. NASICON-Structured Materials for Energy Storage. Adv. Mater. 2017, 29, 1601925. [CrossRef]

23. Anantharamulu, N.; Koteswara Rao, K.; Rambabu, G.; Vijaya Kumar, B.; Radha, V.; Vithal, M. A Wide-Ranging Review on Nasicon Type Materials. J. Mater. Sci. 2011, 46, 2821-2837. [CrossRef]

24. Manthiram, A.; Goodenough, J.B. Lithium Insertion into Fe2(SO4)3 Frameworks. J. Power Sources 1989, 26, 403-408. [CrossRef]

25. Huang, H.; Yin, S.C.; Kerr, T.; Taylor, N.; Nazar, L.F. Nanostructured Composites: A High Capacity, Fast Rate Li3V2(PO4)3/Carbon Cathode for Rechargeable Lithium Batteries. Adv. Mater. 2002, 14, 1525-1528. [CrossRef]

26. Patoux, S.; Wurm, C.; Morcrette, M.; Rousse, G.; Masquelier, C. A Comparative Structural and Electrochemical Study of Monoclinic Li3Fe2(PO4)3 and Li3V2(PO4)3. J. Power Sources 2003, 119, 278-284. [CrossRef]

27. Yin, S.-C.; Grondey, H.; Strobel, P.; Anne, M.; Nazar, L.F. Electrochemical Property: Structure Relationships in Monoclinic Li3-YV2(PO4)3. J. Am. Chem. Soc. 2003, 125, 10402-10411. [CrossRef] [PubMed]

28. Yin, S.C.; Strobel, P.S.; Grondey, H.; Nazar, L.F. Li2.5V2(PO4)3: A Room-Temperature Analogue to the Fast-Ion Conducting High-Temperature $\gamma$-Phase of Li3V2(PO4)3. Chem. Mater. 2004, 16, 1456-1465. [CrossRef]

29. Rui, X.; Yan, Q.; Skyllas-Kazacos, M.; Lim, T.M. Li3V2(PO4)3 Cathode Materials for Lithium-Ion Batteries: A Review. J. Power Sources 2014, 258, 19-38. [CrossRef]

30. Kang, J.; Mathew, V.; Gim, J.; Kim, S.; Song, J.; Im, W.B.; Han, J.; Lee, J.Y.; Kim, J. Pyro-Synthesis of a High Rate Nano-Li3V2 (PO4)3/C Cathode with Mixed Morphology for Advanced Li-Ion Batteries. Sci. Rep. 2014, 4, 1-9. [CrossRef]

31. Saïdi, M.Y.; Barker, J.; Huang, H.; Swoyer, J.L.; Adamson, G. Performance Characteristics of Lithium Vanadium Phosphate as a Cathode Material for Lithium-Ion Batteries. J. Power Sources 2003, 119, 266-272. [CrossRef]

32. Kim, S.; Zhang, Z.; Wang, S.; Yang, L.; Cairns, E.J.; Penner-Hahn, J.E.; Deb, A. Electrochemical and Structural Investigation of the Mechanism of Irreversibility in Li3V2(PO4)3 Cathodes. J. Phys. Chem. C 2016, 120, 7005-7012. [CrossRef]

33. Rui, X.H.; Yesibolati, N.; Chen, C.H. Li3V2(PO4)3/C Composite as an Intercalation-Type Anode Material for Lithium-Ion Batteries. J. Power Sources 2011, 196, 2279-2282. [CrossRef]

34. Gaubicher, J.; Wurm, C.; Goward, G.; Masquelier, C.; Nazar, L. Rhombohedral Form of Li3V2(PO4)3 as a Cathode in Li-Ion Batteries. Chem. Mater. 2000, 12, 3240-3242. [CrossRef]

35. Delmas, C.; Olazcuaga, R.; Cherkaoui, F.; Brochu, R.; Leflem, G. New Family of Phosphates with Formula Na3M2(PO4)3 (M= Ti,V,Cr,Fe). C. R. Seances Acad. Sci. 1978, 287, 169-171.

36. Chotard, J.-N.; Rousse, G.; David, R.; Mentré, O.; Courty, M.; Masquelier, C. Discovery of a Sodium-Ordered Form of Na3V2(PO4)3 below Ambient Temperature. Chem. Mater. 2015, 27, 5982-5987. [CrossRef]

37. Jian, Z.; Yuan, C.; Han, W.; Lu, X.; Gu, L.; Xi, X.; Hu, Y.; Li, H.; Chen, W.; Chen, D.; et al. Atomic Structure and Kinetics of NASICON NaxV2(PO4)3 Cathode for Sodium-Ion Batteries. Adv. Funct. Mater. 2014, 24, 4265-4272. [CrossRef]

38. Golalakrishnan, J.; Kasthuri Rangan, K. NASICON-Type Vanadium Phosphate Synthesized by Oxidative Deintercalation of Sodium from Sodium Vanadium Phosphate (Na3V2(PO4)3). Chem. Mater. 1992, 4, 745-747. [CrossRef]

39. Lalère, F.; Seznec, V.; Courty, M.; David, R.; Chotard, J.N.; Masquelier, C. Improving the Energy Density of Na3V2(PO4)3-Based Positive Electrodes through V/Al Substitution. J. Mater. Chem. A 2015, 3, 16198-16205. [CrossRef]

40. Mason, C.W.; Gocheva, I.; Hoster, H.E.; Dennis, Y.W. Activating Vanadium's Highest Oxidation State in the NASICON Structure. ECS Trans. 2014, 58, 41-46. [CrossRef]

41. Aragón, M.J.; Lavela, P.; Ortiz, G.F.; Tirado, J.L. Benefits of Chromium Substitution in Na3V2(PO4)3 as a Potential Candidate for Sodium-Ion Batteries. ChemElectroChem 2015, 2, 995-1002. [CrossRef]

42. Liu, R.; Xu, G.; Li, Q.; Zheng, S.; Zheng, G.; Gong, Z.; Li, Y.; Kruskop, E.; Fu, R.; Chen, Z.; et al. Exploring Highly Reversible 1.5-Electron Reactions (V3+/V4+/V5+) in Na3VCr(PO4)3 Cathode for Sodium-Ion Batteries. ACS Appl. Mater. Interfaces 2017, 9 , 43632-43639. [CrossRef]

43. Liu, R.; Zheng, S.; Yuan, Y.; Yu, P.; Liang, Z.; Zhao, W.; Shahbazian-Yassar, R.; Ding, J.; Lu, J.; Yang, Y. Counter-Intuitive Structural Instability Aroused by Transition Metal Migration in Polyanionic Sodium Ion Host. Adv. Energy Mater. 2020, 2003256, 1-9. [CrossRef] 
44. Zhou, W.; Xue, L.; Gao, H.; Li, Y.; Xin, S.; Fu, G.; Cui, Z.; Zhu, Y.; Goodenough, J.B. MV(PO4)3 (M= Mn, Fe, Ni) Structure and Properties for Sodium Extraction. Nano Lett. 2016, 16, 7836-7841. [CrossRef]

45. Zakharkin, M.V.; Drozhzhin, O.A.; Tereshchenko, I.V.; Chernyshov, D.; Abakumov, A.M.; Antipov, E.V.; Stevenson, K.J. Enhancing $\mathrm{Na}+$ Extraction Limit through High Voltage Activation of the NASICON-Type Na4MnV(PO4)3 Cathode. ACS Appl. Energy Mater. 2018, 1, 5842-5846. [CrossRef]

46. Zakharkin, M.V.; Drozhzhin, O.A.; Ryazantsev, S.V.; Chernyshov, D.; Kirsanova, M.A.; Mikheev, I.V.; Pazhetnov, E.M.; Antipov, E.V.; Stevenson, K.J. Electrochemical Properties and Evolution of the Phase Transformation Behavior in the NASICON-Type Na3+xMnxV2-x(PO4)3 $(0 \leq x \leq 1)$ Cathodes for Na-Ion Batteries. J. Power Sources 2020, 470, 1-8. [CrossRef]

47. Chen, F.; Kovrugin, V.M.; David, R.; Mentré, O.; Fauth, F.; Chotard, J.N.; Masquelier, C. A NASICON-Type Positive Electrode for Na Batteries with High Energy Density: Na4MnV(PO4)3. Small Methods 2019, 3, 1-9. [CrossRef]

48. Le Meins, J.; Crosnier-Lopez, M.-P.; Hemon-Ribaud, A.; Courbion, G. Phase Transitions in the Na3M2(PO4)2F3 Family $(\mathrm{M}=\mathrm{Al} 3+, \mathrm{V} 3+, \mathrm{Cr} 3+, \mathrm{Fe} 3+, \mathrm{Ga} 3+)$ : Synthesis, Thermal, Structural, and Magnetic Studies. J. Solid State Chem. 1999, 148, 260-277. [CrossRef]

49. Bianchini, M.; Brisset, N.; Fauth, F.; Weill, F.; Elkaim, E.; Suard, E.; Masquelier, C.; Croguennec, L. Na3V2(PO4)2F3 Revisited: A High-Resolution Diffraction Study. Chem. Mater. 2014, 26, 4238-4247. [CrossRef]

50. Shakoor, R.A.; Seo, D.-H.; Kim, H.; Park, Y.-U.; Kim, J.; Kim, S.-W.; Gwon, H.; Lee, S.; Kang, K. A Combined First Principles and Experimental Study on Na3V2(PO4)2F3 for Rechargeable Na Batteries. J. Mater. Chem. 2012, 22, 20535. [CrossRef]

51. Yan, G.; Mariyappan, S.; Rousse, G.; Jacquet, Q.; Deschamps, M.; David, R.; Mirvaux, B.; Freeland, J.W.; Tarascon, J.M. Higher Energy and Safer Sodium Ion Batteries via an Electrochemically Made Disordered Na3V2(PO4)2F3 Material. Nat. Commun. 2019, 10, 1-12. [CrossRef] [PubMed]

52. Bianchini, M.; Fauth, F.; Brisset, N.; Weill, F.; Suard, E.; Masquelier, C.; Croguennec, L. Comprehensive Investigation of the Na3V2(PO4)2F3-NaV2(PO4)2F3 System by Operando High Resolution Synchrotron X-ray Diffraction. Chem. Mater. 2015, 27, 3009-3020. [CrossRef]

53. Broux, T.; Bamine, T.; Simonelli, L.; Stievano, L.; Fauth, F.; Ménétrier, M.; Carlier, D.; Masquelier, C.; Croguennec, L. VIV Disproportionation Upon Sodium Extraction From Na3V2(PO4)2F3 Observed by Operando X-ray Absorption Spectroscopy and State NMR. J. Phys. Chem. C 2017, 121, 4103-4111. [CrossRef]

54. Broux, T.; Bamine, T.; Fauth, F.; Simonelli, L.; Olszewski, W.; Marini, C.; Ménétrier, M.; Carlier, D.; Masquelier, C.; Croguennec, L. Strong Impact of the Oxygen Content in Na3V2(PO4)2F3-YOy $(0 \leqq y \leqq 0.5)$ on Its Structural and Electrochemical Properties. Chem. Mater. 2016, 28, 7683-7692. [CrossRef]

55. Park, Y.U.; Seo, D.H.; Kim, H.; Kim, J.; Lee, S.; Kim, B.; Kang, K. A Family of High-Performance Cathode Materials for Na-Ion Batteries, Na3(VO1-XPO4)2 F1+2x $(0 \leq x \leq 1)$ : Combined First-Principles and Experimental Study. Adv. Funct. Mater. 2014, 24, 4603-4614. [CrossRef]

56. Mariyappan, S.; Wang, Q.; Tarascon, J.M. Will Sodium Layered Oxides Ever Be Competitive for Sodium Ion Battery Applications? J. Electrochem. Soc. 2018, 165, 3714-3722. [CrossRef]

57. Park, Y.U.; Seo, D.H.; Kwon, H.S.; Kim, B.; Kim, J.; Kim, H.; Kim, I.; Yoo, H.I.; Kang, K. A New High-Energy Cathode for a Na-Ion Battery with Ultrahigh Stability. J. Am. Chem. Soc. 2013, 135, 13870-13878. [CrossRef]

58. Serras, P.; Alonso, J.; Sharma, N.; Miguel, J.; Kubiak, P.; Gubieda, M.-L.; Rojo, T. Electrochemical Na Extraction/Insertion of Na3V2O2x(PO4)2F3-2x. Chem. Mater. 2013, 25, 4917-4925. [CrossRef]

59. Morimoto, H.; Ito, D.; Ogata, Y.; Suzuki, T.; Sakamaki, K.; Tsuji, T.; Hirukawa, M.; Matsumoto, A.; Tobishima, S. Charge/Discharge Behavior of Triclinic LiTiOPO4 Anode Materials for Lithium Secondary Batteries. Electrochem. Soc. Jpn. 2016, 84, 878-881. [CrossRef]

60. Barker, J.; Saidi, M.Y.; Swoyer, J.L. Electrochemical Insertion Properties of the Novel Lithium Vanadium Fluorophosphate, LiVPO4F. J. Electrochem. Soc. 2003, 150, 1394-1398. [CrossRef]

61. Badraoui, A.E.; Pivan, J.-Y.; Maunaye, M.; Pena, O.; Louer, M.; Louer, D. Order-Disorder Phenomena in Vanadium Phosphates. Structures and Properties of Tetragonal and Monoclinic VPO4·H2O. Ann. Chim. Sci. Matériaux 1998, 23, 97-101. [CrossRef]

62. Lii, K.H.; Li, H.; Cheng, C.; Wang, S. Synthesis and Structural Characterization of Sodium Vanadyl (IV) Orthophosphate NaVOPO4. Z. Krist. Cryst. Mater. 2010, 197, 67-73. [CrossRef]

63. Bianchini, M.; Ateba-Mba, J.M.; Dagault, P.; Bogdan, E.; Carlier, D.; Suard, E.; Masquelier, C.; Croguennec, L. Multiple Phases in the $\varepsilon$-VPO4O-LiVPO4O-Li2VPO4O System: A Combined Solid State Electrochemistry and Diffraction Structural Study. J. Mater. Chem. A 2014, 2, 10182-10192. [CrossRef]

64. Song, Y.; Zavalij, P.Y.; Whittingham, M.S. $\varepsilon$-VOPO4: Electrochemical Synthesis and Enhanced Cathode Behavior. J. Electrochem. Soc. 2005, 152, 721-728. [CrossRef]

65. Boivin, E.; Chotard, J.-N.; Ménétrier, M.; Bourgeois, L.; Bamine, T.; Carlier, D.; Fauth, F.; Suard, E.; Masquelier, C.; Croguennec, L. Structural and Electrochemical Studies of a New Tavorite Composition LiVPO4OH. J. Mater. Chem. A 2016, 4, 11030-11045. [CrossRef]

66. Lee Harrison, K.; Bridges, C.; Segre, C.; Varnado, D.; Applestone, D.; Bielawski, C.; Paranthaman, M.; Manthiram, A. Chemical and Electrochemical Lithiation of LiVOPO4 Cathodes for Lithium-Ion Batteries. Chem. Mater. 2014, 26, 3849-3861. [CrossRef] 
67. Lin, Y.; Wen, B.; Wiaderek, K.; Sallis, S.; Liu, H.; Lapidus, S.; Borkiewicz, O.; Quackenbush, N.; Chernova, N.; Karki, K.; et al. Thermodynamics, Kinetics and Structural Evolution of $\varepsilon$-LiVOPO4 over Multiple Lithium Intercalation. Chem. Mater. 2016, 28, 1794-1805. [CrossRef]

68. Barker, J.; Saidi, M.Y.; Swoyer, J.L. A Comparative Investigation of the Li Insertion Properties of the Novel Fluorophosphate Phases, NaVPO4F and LiVPO4F. J. Electrochem. Soc. 2004, 151, 1670-1677. [CrossRef]

69. Barker, J.; Gover, R.K.B.; Burns, P.; Bryan, A.; Saidi, M.Y.; Swoyer, J.L. Structural and Electrochemical Properties of Lithium Vanadium Fluorophosphate, LiVPO4F. J. Power Sources 2005, 146, 516-520. [CrossRef]

70. Ellis, B.L.; Ramesh, T.N.; Davis, L.J.M.; Goward, G.R.; Nazar, L.F. Structure and Electrochemistry of Two-Electron Redox Couples in Lithium Metal Fluorophosphates Based on the Tavorite Structure. Chem. Mater. 2011, 23, 5138-5148. [CrossRef]

71. Boivin, E. Crystal Chemistry of Vanadium Phosphates as Positive Electrode Materials for Li-Ion and Na-Ion Batteries. Ph.D. Thesis, University of Picardie Jules Verne, Amiens, France, 2017.

72. Ateba Mba, J.-M.; Croguennec, L.; Basir, N.I.; Barker, J.; Masquelier, C. Lithium Insertion or Extraction from/into Tavorite-Type LiVPO4F: An In Situ X-Ray Diffraction Study. J. Electrochem. Soc. 2012, 159, 1171-1175. [CrossRef]

73. Piao, Y.; Qin, Y.; Ren, Y.; Heald, S.M.; Sun, C.; Zhou, D.; Polzin, B.J.; Trask, S.E.; Amine, K.; Wei, Y.; et al. A XANES Study of LiVPO4F: A Factor Analysis Approach. Phys. Chem. Chem. Phys. 2014, 16, 3254-3260. [CrossRef] [PubMed]

74. Zhong, S.; Chen, W.; Li, Y.; Zou, Z.; Liu, C. Synthesis of LiVPO4F with High Electrochemical Performance by Sol-Gel Route. Trans. Nonferrous Met. Soc. China 2010, 20, 275-278. [CrossRef]

75. Rangaswamy, P.; Shetty, V.R.; Suresh, G.S.; Mahadevan, K.M.; Nagaraju, D.H. Enhanced Electrochemical Performance of LiVPO4F/f-Graphene Composite Electrode Prepared via Ionothermal Process. J. Appl. Electrochem. 2017, 47. [CrossRef]

76. Messinger, R.J.; Ménétrier, M.; Salager, E.; Boulineau, A.; Duttine, M.; Carlier, D.; Ateba Mba, J.-M.; Croguennec, L.; Masquelier, C.; Massiot, D.; et al. Revealing Defects in Crystalline Lithium-Ion Battery Electrodes by Solid-State NMR: Applications to LiVPO4F. Chem. Mater. 2015, 27, 5212-5221. [CrossRef]

77. Bamine, T.; Boivin, E.; Boucher, F.; Messinger, R.J.; Salager, E.; Deschamps, M.; Masquelier, C.; Croguennec, L.; Ménétrier, M.; Carlier, D. Understanding Local Defects in Li-Ion Battery Electrodes through Combined DFT/NMR Studies: Application to LiVPO4F. J. Phys. Chem. C 2017, 121, 3219-3227. [CrossRef]

78. Kim, M.; Lee, S.; Kang, B. Fast-Rate Capable Electrode Material with Higher Energy Density than LiFePO4: 4.2 V LiVPO4F Synthesized by Scalable Single-Step Solid-State Reaction. Adv. Sci. 2015, 3, 1500366. [CrossRef]

79. Kim, M.; Lee, S.; Kang, B. High Energy Density Polyanion Electrode Material: LiVPO4O1-XFx $(x \approx 0.25)$ with Tavorite Structure. Chem. Mater. 2017, 29, 4690-4699. [CrossRef]

80. Boivin, E.; David, R.; Chotard, J.N.; Bamine, T.; Iadecola, A.; Bourgeois, L.; Suard, E.; Fauth, F.; Carlier, D.; Masquelier, C.; et al. LiVPO4F1-YOy Tavorite-Type Compositions: Influence of the Vanadyl-Type Defects' Concentration on the Structure and Electrochemical Performance. Chem. Mater. 2018, 30, 5682-5693. [CrossRef]

81. Boivin, E.; Iadecola, A.; Fauth, F.; Chotard, J.N.; Masquelier, C.; Croguennec, L. Redox Paradox of Vanadium in Tavorite LiVPO4F1-YOy. Chem. Mater. 2019, 31, 7367-7376. [CrossRef]

82. Wurm, C.; Morcrette, M.; Rousse, G.; Dupont, L.; Masquelier, C. Lithium Insertion/Extraction into/from LiMX2O7 Compositions $(\mathrm{M}=\mathrm{Fe}, \mathrm{V} . ; \mathrm{X}=\mathrm{P}$, As) Prepared via a Solution Method. Chem. Mater. 2002, 14, 2701-2710. [CrossRef]

83. Barker, J.; Gover, R.K.B.; Burns, P.; Bryan, A. LiVP2O7: A Viable Lithium-Ion Cathode Material? Electrochem. Solid State Lett. 2005, 8, 446-448. [CrossRef]

84. Deng, C.; Zhang, S. 1D Nanostructured Na7V4(P2O7)4(PO4) as High-Potential and Superior-Performance Cathode Material for Sodium-Ion Batteries. Appl. Mater. Interfaces 2014, 6, 9111-9117. [CrossRef] [PubMed]

85. Kovrugin, V.; Chotard, J.-N.; Fauth, F.; Jamali, A.; David, R.; Christian, M. Structural and Electrochemical Studies of Novel Batteries. J. Mater. Chem. A 2017, 5, 14365-14376. [CrossRef]

86. Kim, J.; Yoon, G.; Kim, H.; Park, Y.U.; Kang, K. Na3V(PO4)2: A New Layered-Type Cathode Material with High Water Stability and Power Capability for Na-Ion Batteries. Chem. Mater. 2018, 30, 3683-3689. [CrossRef]

87. Liu, R.; Liang, Z.; Xiang, Y.; Zhao, W.; Liu, H.; Chen, Y. Recognition of V3+/V4+/V5+ Multielectron Reactions in Na3V(PO4)2: A Potential High Energy Density Cathode for Sodium-Ion Batteries. Molecules 2020, 25, 1000. [CrossRef]

88. Sandineni, P.; Madria, P.; Ghosh, K.; Choudhury, A. A Square Channel Vanadium Phosphite Framework as High Voltage Cathode for Li- and Na- Ion Batteries. Mater. Adv. 2020. [CrossRef]

89. Kuang, Q.; Xu, J.; Zhao, Y.; Chen, X.; Chen, L. Layered Monodiphosphate Li9V3(P2O7)3(PO4)2: A Novel Cathode Material for Lithium-Ion Batteries. Electrochim. Acta 2011, 56, 2201-2205. [CrossRef]

90. Deng, C.; Zhang, S.; Zhao, B. First Exploration of Ultra Fine Na7V3(P2O7)4 as a High-Potential Cathode Material for Sodium-Ion Battery. Energy Storage Mater. 2016, 4, 71-78. [CrossRef]

91. Reynaud, M.; Wizner, A.; Katcho, N.A.; Loaiza, L.C.; Galceran, M.; Carrasco, J.; Rojo, T.; Armand, M.; Casas-Cabanas, M. Sodium Vanadium Nitridophosphate Na3V(PO3)3N as a High-Voltage Positive Electrode Material for Na-Ion and Li-Ion Batteries. Electrochem. Commun. 2017, 84, 14-18. [CrossRef]

92. Boivin, E.; Chotard, J.-N.; Bamine, T.; Carlier, D.; Serras, P.; Veronica, P.; Rojo, T.; Iadecola, A.; Dupont, L.; Bourgeois, L.; et al. Vanadyl-Type Defects in Tavorite-like NaVPO4F: From the Average Long Range Structure to Local Environments. J. Mater. Chem. A 2017, 5, 25044-25055. [CrossRef] 
93. Fedotov, S.S.; Khasanova, N.R.; Samarin, A.S.; Drozhzhin, O.A.; Batuk, D.; Karakulina, O.M.; Hadermann, J.; Abakumov, A.M.; Antipov, E.V. AVPO4F (A = Li, K): A 4 V Cathode Material for High-Power Rechargeable Batteries. Chem. Mater. 2016, 28, 411-415. [CrossRef]

94. Zhang, B.; Dugas, R.; Rousse, G.; Rozier, P.; Abakumov, A.M.; Tarascon, J.M. Insertion Compounds and Composites Made by Ball Milling for Advanced Sodium-Ion Batteries. Nat. Commun. 2016, 7, 1-9. [CrossRef] [PubMed]

95. Makimura, Y.; Cahill, L.S.; Iriyama, Y.; Goward, G.R.; Nazar, L.F. Layered Lithium Vanadium Fluorophosphate, Li 5 V(PO 4 ) 2 F 2: A 4 V Class Positive Electrode Material for Lithium-Ion Batteries. Chem. Mater. 2008, 20, 4240-4248. [CrossRef]

96. Liang, Z.; Zhang, X.; Liu, R.; Ortiz, G.F.; Zhong, G.; Xiang, Y.; Chen, S.; Mi, J.; Wu, S.; Yang, Y. New Dimorphs of Na5V(PO4)2F2 as an Ultrastable Cathode Material for Sodium-Ion Batteries. ACS Appl. Energy Mater. 2020, 3, 1181-1189. [CrossRef]

97. Barker, J.; Saidi, M.Y.; Swoyer, J.L. Electrochemical Properties of $\beta$-LiVOPO4 Prepared by Carbothermal Reduction. J. Electrochem. Soc. 2004, 151, 796-800. [CrossRef]

98. He, G.; Kan, W.; Manthiram, A. $\beta$-NaVOPO4 Obtained by a Low-Temperature Synthesis Process: A New 3.3 V Cathode for Sodium-Ion Batteries. Chem. Mater. 2016, 28, 1503-1512. [CrossRef]

99. He, G.; Bridges, C.A.; Manthiram, A. Crystal Chemistry of Electrochemically and Chemically Lithiated Layered $\alpha$-LiVOPO4. Chem. Mater. 2015, 27, 6699-6707. [CrossRef]

100. Satya Kishore, M.; Pralong, V.; Caignaert, V.; Malo, S.; Hebert, S.; Varadaraju, U.V.; Raveau, B. Topotactic Insertion of Lithium in the Layered Structure Li4VO(PO4)2: The Tunnel Structure Li5VO(PO4)2. J. Solid State Chem. 2008, 181, 976-982. [CrossRef]

101. Kim, J.; Kim, H.; Lee, S. High Power Cathode Material Na4VO(PO4)2 with Open Framework for Na Ion Batteries. Chem. Mater. 2017, 29, 3363-3366. [CrossRef]

102. Kishore, M.S.; Pralong, V.; Caignaert, V.; Varadaraju, U.V.; Raveau, B. A New Lithium Vanadyl Diphosphate Li2VOP2O7: Synthesis and Electrochemical Study. Solid State Sci. 2008, 10, 1285-1291. [CrossRef]

103. Manthiram, A.; Goodenough, J.B. Lithium Insertion into Fe2(MO4)3 Frameworks: Comparison of $\mathrm{M}=\mathrm{W}$ with $\mathrm{M}=\mathrm{MO}$. J. Solid State Chem. 1987, 71, 349-360. [CrossRef]

104. Ben Yahia, M.; Lemoigno, F.; Rousse, G.; Boucher, F.; Tarascon, J.-M.; Doublet, M.-L. Origin of the 3.6 V to 3.9 V Voltage Increase in the LiFeSO4F Cathodes for Li-Ion Batteries. Energy Environ. Sci. 2012, 5, 9584. [CrossRef]

105. Parapari, S.S.; Ateba Mba, J.M.; Tchernychova, E.; Mali, G.; Arčon, I.; Kapun, G.; Gülgün, M.A.; Dominko, R. Effects of a Mixed $\mathrm{O} / \mathrm{F}$ Ligand in the Tavorite-Type LiVPO4O Structure. Chem. Mater. 2020, 32, 262-272. [CrossRef]

106. Boivin, E.; Chotard, J.N.; Ménétrier, M.; Bourgeois, L.; Bamine, T.; Carlier, D.; Fauth, F.; Masquelier, C.; Croguennec, L. Oxidation under Air of Tavorite LiVPO4F: Influence of Vanadyl-Type Defects on Its Electrochemical Properties. J. Phys. Chem. C 2016, 120, 26187-26198. [CrossRef]

107. Nguyen, L.H.B.; Iadecola, A.; Belin, S.; Olchowka, J.; Masquelier, C.; Carlier, D.; Croguennec, L. A Combined Operando Synchrotron X-ray Absorption Spectroscopy and First-Principles Density Functional Theory Study to Unravel the Vanadium Redox Paradox in the Na3V2(PO4)2F3-Na3V2(PO4)2FO2 Compositions. J. Phys. Chem. C 2020, 124, 23511-23522. [CrossRef]

108. Bamine, T.; Boivin, E.; Masquelier, C.; Croguennec, L.; Salager, E.; Carlier, D. Local Atomic and Electronic Structure in the LiVPO4(F,O) Tavorite-Type Materials from Solid State NMR Combined with DFT Calculations. Magn. Reson. Chem. 2020, 58, 1109-1117. [CrossRef]

109. Ni, S.; Liu, J.; Chao, D.; Mai, L. Vanadate-Based Materials for Li-Ion Batteries: The Search for Anodes for Practical Applications. Adv. Energy Mater. 2019, 9, 1803324. [CrossRef] 